Review

\title{
The Impact of TRPVI on Cancer Pathogenesis and Therapy: A Systematic Review
}

\author{
$\mathrm{Li} \mathrm{Li}^{1}$, Cheng Chen ${ }^{1}$, Chengyao Chiang1, Tian Xiao', Yangchao Chen², Yongxiang Zhao ${ }^{3}$, Duo Zheng ${ }^{\boxplus}$ \\ 1. Guangdong Provincial Key Laboratory of Regional Immunity and Diseases, Shenzhen University International Cancer Center, Department of Cell Biology \\ and Genetics, School of Medicine, College of Life Sciences and Oceanography, Shenzhen University, Shenzhen 518055, China. \\ 2. School of Biomedical Sciences, Faculty of Medicine, The Chinese University of Hong Kong, Shatin, NT, Hong Kong. \\ 3. National Center for International Research of Biological Targeting Diagnosis and Therapy (Guangxi Key Laboratory of Biological Targeting Diagnosis and \\ Therapy Research), Guangxi Medical University, Nanning, China.
}

$\triangle$ Corresponding author: Duo Zheng, Shenzhen University International Cancer Center, Department of Cell Biology and Genetics, School of Medicine, A7-450, Shenzhen University, Lihu Campus, Nanshan District, Shenzhen 518055, China. Tel: 86-755-86674681; E-mail: dzheng@szu.edu.cn.

(c) The author(s). This is an open access article distributed under the terms of the Creative Commons Attribution License (https://creativecommons.org/licenses/by/4.0/). See http://ivyspring.com/terms for full terms and conditions.

Received: 2021.02.28; Accepted: 2021.04.23; Published: 2021.05.11

\begin{abstract}
The transient receptor potential cation channel subfamily $V$ member 1 (TRPV1) is a transmembrane protein that can be activated by various physical and chemical stimuli and is associated with pain transduction. In recent years, TRPVI was discovered to play essential roles in cancer tumorigenesis and development, as TRPV1 expression levels are altered in numerous cancer cell types. Several investigations have discovered direct associations between TRPVI and cancer cell proliferation, cell death, and metastasis. Furthermore, about two dozen TRPVI agonists/antagonists are under clinical trial, as TRPV1 is a potential drug target for treating various diseases. Hence, more researchers are focusing on the effects of TRPV1 agonists or antagonists on cancer tumorigenesis and development. However, both agonists and antagonists may reveal anti-cancer effects, and the effect may function via or be independent of TRPV1. In this review, we provide an overview of the impact of TRPVI on cancer cell proliferation, cell death, and metastasis, as well as on cancer therapy and the tumor microenvironment, and consider the implications of using TRPVI agonists and antagonists for future research and potential therapeutic approaches.
\end{abstract}

Key words: TRPV1, proliferation, cell death, metastasis, therapy, microenvironment.

\section{Introduction}

Cancer is increasingly recognized as a serious public health concern worldwide; however, the mechanisms of tumorigenesis and development are complex and not well understood. The transformation from normal cells to cancer cells is caused by numerous alterations in various signaling pathways, which lead to enhanced cell proliferation, inhibition of programmed cell death, migration, and invasion.

Many proteins in cancer cells exhibit enhanced or reduced expression levels compared with the levels in normal cells, and these proteins play important roles in tumorigenesis and development. The recently identified transient receptor potential (TRP) channels are subject to expression changes in cancer cells [1, 2]. So far, the most studied members of the family have been TRPC1, TRPV6, TRPM1, and TRPM8 [3].
However, in the previous two decades, researchers have shown an increased interest in TRP subfamily $\mathrm{V}$ member 1 (V1), as it appears to play multiple roles in cancer $[4,5]$. Alterations in both the expression and activity of TRPV1 are associated with tumorigenesis and therapy. The activation of the cation channel TRPV1 by heat and small molecules permeabilizes cells to allow $\mathrm{Ca}^{2+}$ and $\mathrm{Na}^{+}$influx [6]. A considerable amount of literature has been published on the effects of TRPV1 agonists and antagonists on tumorigenesis and development.

In this review, we summarize the observations reported to date of the changes in TRPV1 expression and channel activity associated with cancers and the effects of these alterations on cancer cell proliferation, death, and metastasis, and the tumor 
microenvironment. We further discuss the therapeutic potential of targeting TRPV1 in cancer cells. To comprehensively understand the effects of TRPV1 activation on proliferation, cell death, metastasis, and therapy, we provide tables detailing the investigations reviewed so far regarding relevant drug applications, drug concentrations, tissue/cell types, and their effects on the treatment of tumors.

\section{What is TRPV1}

The human TRPV1 protein is encoded by the TRPV1 gene located on chromosome 17p13. TRPV1 belongs to the transient receptor potential channel vanilloid subfamily and is also known as the capsaicin receptor and vanilloid receptor 1 (VR1). TRPV1 predominantly forms a homotetramer, with each subunit consisting of six transmembrane segments, a pore-forming loop between the fifth and sixth transmembrane domains, and cytoplasmic C- and $\mathrm{N}$-terminal domains [7-10]. Initially, TRPV1 was found to be expressed prominently in small-tomedium-sized neurons of the dorsal root, trigeminal, and vagal ganglia $[8,11]$, and was discovered to be involved in pain transduction [12]. Later, TRPV1 expression was reported in non-neuronal system cells, such as arteriolar smooth muscle cells $[13,14]$ and the bladder urothelium [15]. TRPV1 is a nonselective cation channel that can be activated by different physical and chemical stimuli, including temperatures over $43^{\circ} \mathrm{C}$, acidic conditions $(\mathrm{pH}<6)$, and vanilloids $[8,9,16]$. The activation of TRPV1 induces the cellular influx of $\mathrm{Ca}^{2+}$ and $\mathrm{Na}^{+}$ions [17-19], and the excess intracellular $\mathrm{Ca}^{2+}$ and $\mathrm{Na}^{+}$ leads to cell death [20]. Numerous putative endogenous and exogenous agonists and antagonists of TRPV1 have been identified and summarized (Table 1). Because TRPV1 is a promising therapeutic target in many human diseases and conditions [21, 22], about two dozen TRPV1 agonists/antagonists are being used in clinical trials, many of which are concerned with pain and inflammation $[23,24]$.

\section{Expression of TRPV1 in cancers}

TRPV1 expression has been reported to be higher in human primary brain tumors than tumor-free brains. Furthermore, its expression positively correlates with the grading of tumors [64]. Compared with in a normal pancreas, TRPV1 mRNA expression is significantly upregulated in human pancreatic cancer and chronic pancreatitis [65]. Elevated TRPV1 expression has also been verified in squamous cell carcinoma of the human tongue, prostate carcinoma, and breast cancer [66-68]. All the above published work indicated that TRPV1 expression is upregulated in cancers.
Table 1. Endogenous and exogenous ligands of TRPV1.

\begin{tabular}{|c|c|}
\hline Ligands & Ref. \\
\hline \multicolumn{2}{|l|}{ Endogenous agonists: } \\
\hline Anandamide & [25] \\
\hline $\mathrm{N}$-arachidonoyldopamine & [26] \\
\hline N-oleoyldopamine & [27] \\
\hline $\mathrm{R}(+)$-methanandamide & [25] \\
\hline 12- and 15-hydroperoxyeicosatetraenoic acid & [28] \\
\hline 5- and 15-hydroxyeicosatetraenoic acid & [28] \\
\hline Leukotriene B4 & [28] \\
\hline 9- and 13-hydroxy-octadecadienoic acid & [12] \\
\hline 9- and 13-oxo-octadecadienoic acid & [12] \\
\hline Oleoylethanolamide & [29] \\
\hline Palmitoylethanolamide & [30] \\
\hline Lysophosphatidic acid & [31] \\
\hline Oxytocin & [32] \\
\hline \multicolumn{2}{|l|}{ Exogenous agonists } \\
\hline 2-aminoethoxydiphenyl borate & [33] \\
\hline 4a-phorbol-12,13-didecanoate & [34] \\
\hline Ornithoctonus huwena toxin ['double-knot' toxin (DkTx)] & [35] \\
\hline Capsaicin & {$[8]$} \\
\hline Piperine & [36] \\
\hline Resiniferatoxin & [37] \\
\hline Gingerol & [38] \\
\hline Evodiamine & [39] \\
\hline Cannabidiol & [40] \\
\hline Cannabigerol & [41] \\
\hline Polygodial & [42] \\
\hline Vanillotoxin & [43] \\
\hline MD-652 & [44] \\
\hline Linopirdine & [45] \\
\hline \multicolumn{2}{|l|}{ Endogenous antagonists } \\
\hline Resolvin D2 & [46] \\
\hline Noradrenaline & [47] \\
\hline \multicolumn{2}{|l|}{ Exogenous antagonists } \\
\hline Capsazepine & [48] \\
\hline Iodo-resiniferatoxin & [49] \\
\hline Hypericum perforatum & [50] \\
\hline JNJ-17203212 & [51] \\
\hline ВСТC & [52] \\
\hline Thapsigargin & [53] \\
\hline Yohimbine & [54] \\
\hline JYL 1421 & [55] \\
\hline Caffeic acid & [56] \\
\hline Asivatrep & [57] \\
\hline SB-366791 & [58] \\
\hline A-1165442 & [59] \\
\hline AMG 9810 & {$[60]$} \\
\hline AG489, AG505 & [61] \\
\hline $\begin{array}{l}\text { ABT-102, AMG-517, AZD-1386, DWP-05195, GRC-6211, JTS-653, } \\
\text { MK-2295, PHE377, SB-705498 }\end{array}$ & $\begin{array}{l}{[62,} \\
63]\end{array}$ \\
\hline
\end{tabular}

\section{TRPV1 regulates proliferation}

TRPV1 channel activation increases the intracellular $\mathrm{Ca}^{2+}$ concentration, and $\mathrm{Ca}^{2+}$ signaling plays an essential role in cancer cell proliferation, regulation, and survival [69]. A few studies have investigated the associations between changes in TRPV1 protein expression and the regulation of cancer cell proliferation. The majority of studies focused on the effects of TRPV1 agonists or antagonists on cell proliferation; however, some of these chemicals regulate proliferation independently of TRPV1 because they either play roles in cells 
without TRPV1 expression or affect other receptors. In this section, we describe the roles and underlying mechanisms of the TRPV1 gene and the effects of TRPV1 agonists and antagonists, both independently of and dependent on TRPV1 and other receptors, on proliferation (Table 2).

\section{TRPV1 expression suppresses cell proliferation}

The overexpression of TRPV1 in intestinal epithelial HCT116 cells suppressed the phosphorylation of epidermal growth factor receptor (EGFR) at Y1068, a receptor that is associated with a variety of pro-proliferative signaling pathways [70]. According to the results of in vitro studies, the depletion of Trpo1 in mice led to the constitutive phosphorylation of EGFR at Y1068 and subsequently increased the expression of the oncogenes $c$-Fos and $c-M y c$, indicating that TRPV1 is a negative regulator in intestinal tumorigenesis [70]. The proliferation of human melanoma A2058 and A375 cells was inhibited after TRPV1 overexpression, as the overexpression induced apoptosis via the calcineurin-ATF3-p53 pathway in these cells [71]. It was reported that TRPV1 overexpression prevented the proliferation of human pancreatic cancer PANC-1 cells and human skin carcinoma A431 cells by promoting EGFR ubiquitination and degradation [72, 73]. The evidence presented thus far supports the hypothesis that TRPV1 acts to suppress cancer cell proliferation.

Table 2. Role of TRPV1 in Proliferation.

\begin{tabular}{|c|c|c|c|c|c|}
\hline Drug & $\begin{array}{l}\text { Dose } \\
(\mu \mathrm{M})\end{array}$ & $\begin{array}{l}\text { Duration } \\
\text { (h) }\end{array}$ & Tissue/Cell Type & Mechanism & Outcomes \\
\hline & & & $\begin{array}{l}\text { Human colorectal cancer HCT116 } \\
\text { cells }\end{array}$ & $\begin{array}{l}\text { Overexpression of TRPV1 suppressed EGFR phosphorylation at } \\
\text { Y1068 }\end{array}$ & Proliferation $\downarrow[70]$ \\
\hline & & & Trpv1 knockout mice & $\begin{array}{l}\text { TRPV1 knockout increased constitutive EGFR Y1068 } \\
\text { phosphorylation and PCNA, c-Fos and } c-M y c \text { expression levels }\end{array}$ & Proliferation $\uparrow[70]$ \\
\hline & & & $\begin{array}{l}\text { Human colorectal cancer HCT116 } \\
\text { cells }\end{array}$ & $\begin{array}{l}\text { TRPV1 activation activates calpain and PTP1B, which } \\
\text { dephosphorylates EGFR }\end{array}$ & Proliferation $\downarrow[70]$ \\
\hline & & & $\begin{array}{l}\text { Human melanoma A2058 and } \\
\text { A375 cells }\end{array}$ & $\begin{array}{l}\text { Overexpression of TRPV1 activated p53 and, subsequently, } \\
\text { upregulated its downstream target genes p21, PUMA, and mdm } 2 \text { to } \\
\text { induce apoptosis }\end{array}$ & Proliferation $\downarrow[71]$ \\
\hline & & & $\begin{array}{l}\text { Human pancreatic cancer cell line, } \\
\text { PANC-1 }\end{array}$ & $\begin{array}{l}\text { Overexpression of TRPV1 downregulates EGFR levels by inducing } \\
\text { EGFR ubiquitination and degradation }\end{array}$ & Proliferation $\downarrow[72]$ \\
\hline & & & Human skin A431 cells & $\begin{array}{l}\text { Overexpression of TRPV1 promotes EGFR ubiquitylation and } \\
\text { lysosomal degradation }\end{array}$ & Proliferation $\downarrow[73]$ \\
\hline Capsaicin & 100 & 24 & $\begin{array}{l}\text { Human urothelial cancer RT4 } \\
\text { cells }\end{array}$ & $\begin{array}{l}\text { Induced cell cycle arrest in G0/G1 phase and apoptosis by } \\
\text { activating p53 to upregulate Fas/CD95 in TRPV1-overexpressing } \\
\text { cells }\end{array}$ & Proliferation $\downarrow[74]$ \\
\hline Capsaicin & $50-400$ & $24-48$ & $\begin{array}{l}\text { Human renal carcinoma 786-O } \\
\text { cells }\end{array}$ & Activated p38 and JNK MAPK pathways to induce apoptosis & Proliferation $\downarrow[75]$ \\
\hline Capsaicin & $0.1-20$ & 48 & $\begin{array}{l}\text { Human prostate tumor } \\
\text { androgen-responsive LNCaP cells }\end{array}$ & $\begin{array}{l}\text { Activated PI3K and p } 44 / 42 \text { MAPK pathways to suppress ceramide } \\
\text { production and increased androgen receptor expression }\end{array}$ & Proliferation $\uparrow[76]$ \\
\hline Capsaicin & 15 & $96-120$ & Human ESCC cell lines Eca109 & & Proliferation $\uparrow[77]$ \\
\hline Capsaicin & 100 & 24 & $\begin{array}{l}\text { Human hepatocellular carcinoma } \\
\text { PLC/PRF } / 5 \text { cells }\end{array}$ & $\begin{array}{l}\text { Induced apoptosis by increasing the phosphorylation level of ERK } \\
\text { and attenuating STAT3 phosphorylation }\end{array}$ & Proliferation $\downarrow[81]$ \\
\hline Capsaicin & 20 & 36 & $\begin{array}{l}\text { Human prostate tumor } \\
\text { androgen-resistant PC-3 cells }\end{array}$ & $\begin{array}{l}\text { Induced apoptosis by producing ROS originating from the } \\
\text { mitochondria and decreasing perturbations in the inner } \\
\text { transmembrane potential }(\triangle \Psi \mathrm{m}) \text { independently of TRPV1 }\end{array}$ & Proliferation $\downarrow[82]$ \\
\hline Capsaicin & 100 & $24-72$ & $\begin{array}{l}\text { Human pancreatic } \\
\text { neuroendocrine tumor BON and } \\
\text { QGP-1 cells }\end{array}$ & $\begin{array}{l}\text { Disrupted mitochondrial membrane potential and suppressed ATP } \\
\text { synthesis to induce apoptosis }\end{array}$ & Proliferation $\downarrow[83]$ \\
\hline Capsaicin & 75 & $24 / 48$ & $\begin{array}{l}\text { Human nasopharyngeal } \\
\text { carcinoma CNE2 and SUNE1 cells }\end{array}$ & Inhibited MKK3-induced p38 activation & Proliferation $\downarrow[84]$ \\
\hline Capsaicin & 3 & $48 / 96$ & $\begin{array}{l}\text { Human breast carcinoma cell line } \\
\text { MCF-7 cells }\end{array}$ & & Proliferation $\uparrow[90]$ \\
\hline Cannabidiol & 10 & 48 & $\begin{array}{l}\text { Human breast carcinoma cell line } \\
\text { MBA-MD-231 cells }\end{array}$ & $\begin{array}{l}\text { Induced apoptosis via activation of CB2 and TRPV1 to elevate } \\
\text { reactive oxygen species }\end{array}$ & Proliferation $\downarrow[78]$ \\
\hline Cannabidiol & 10 & 24 & $\begin{array}{l}\text { Human colon adenocarcinoma } \\
\text { cell line Caco- } 2 \text { cells }\end{array}$ & $\begin{array}{l}\text { Reduced the phosphorylation level of Akt, which was dependent } \\
\text { on TRPV1 and CB1 }\end{array}$ & Proliferation $\downarrow[79]$ \\
\hline Noradrenaline & 100 & 24 & $\begin{array}{l}\text { Human prostate tumor } \\
\text { androgen-resistant PC-3 cells }\end{array}$ & $\begin{array}{l}\text { Activated both alpha 1D-AR and TRPV1 and, subsequently, elicited } \\
\text { the PLC/PKC/ERK pathways }\end{array}$ & Proliferation $\uparrow[80]$ \\
\hline Cannabigerol & 10 & 24 & $\begin{array}{l}\text { Human colon adenocarcinoma } \\
\text { cell line Caco- } 2 \text { cells }\end{array}$ & $\begin{array}{l}\text { Stimulated ROS generation, increased CHOP expression level, and } \\
\text { promoted apoptosis }\end{array}$ & Proliferation $\downarrow[85]$ \\
\hline AEA & 10 & $24-72$ & $\begin{array}{l}\text { The murine neuroblastoma cell } \\
\text { line N1E-115 }\end{array}$ & Seemed to occur via a lipid raft-dependent mechanism & Proliferation $\downarrow[86]$ \\
\hline
\end{tabular}




\section{TRPVI agonist capsaicin affects cell proliferation dependent on TRPVI}

Ligand-induced autophosphorylation of the EGFR results in phospholipase C (PLC) activation, which cleaves phosphatidylinositol-4,5-bisphosphate $\left(\mathrm{PIP}_{2}\right)$ into diacylglycerol (DAG) and inositol triphosphate $\left(\mathrm{IP}_{3}\right)$. Then IP3 triggers TRPV1 and $\mathrm{Ca}^{2+}$ influx, which activates calpain and subsequently protein tyrosine phosphatase 1B (PTP1B). PTP1B then dephosphorylates EGFR to inhibit intestinal epithelial HCT116 cell proliferation [70]. Amantini et al. found that the capsaicin-induced arrest of the cell cycle in the G0/G1 phase and apoptosis mediated by the ATM-p53 and ATM-Fas/CD95 pathways inhibited the proliferation of human urothelial cancer RT4 cells but not that of TCCSUP, J82, or EJ urothelial cancer cell lines, as TRPV1 showed high expression levels in RT4 cells [74]. Furthermore, this antiproliferation effect was completely rescued by capsazepine and SB366791, two antagonists of TRPV1 [74]. Another study illustrated the capsaicin suppression of human renal carcinoma 786-O cell proliferation, which was also reversed by capsazepine treatment [75]. Additionally, capsaicin induced apoptosis by activating the p38 and JNK/MAPK pathways, suppressing proliferation [75]. However, the opposite effect of capsaicin on proliferation has also been reported. For example, Malagarie-Cazenave et al. discovered that capsaicin promoted human prostate tumor androgen-responsive LNCaP cell growth by activating the PI3K and p44/42 MAPK pathways to suppress ceramide production as well as increasing androgen receptor (AR) expression [76]. The proliferative effect of capsaicin on LNCaP cells was reversed by the TRPV1 antagonists 5-iodoresiniferatoxin (I-RTX), capsazepine, and SB366791 [76]. In a similar study, Huang et al. demonstrated that capsaicin treatment promoted the proliferation of human esophageal squamous cell carcinoma (ESCC) Eca109 cells, and the effect was abolished by the TRPV1 receptor antagonist AMG9810 [77]. The information detailed in Table 2 indicates that the effect of capsaicin on proliferation is dependent on its concentration: low-dose capsaicin promotes cancer cell proliferation, whereas high-dose capsaicin prevents proliferation.

\section{Some agonists affect cell proliferation via both TRPVI and other receptors}

Some pharmacological regulators activate not only TRPV1 but also other reporters to affect cancer cell proliferation. For instance, cannabidiol prevented the proliferation of human breast cancer MBA-MD-231 cells through the activation of cannabinoid receptor type 2 (CB2) and TRPV1 to elevate intracellular $\mathrm{Ca}^{2+}$ and ROS generation and induce apoptosis [78]. The respective CB2 and TRPV1 antagonists SR144528 and I-RTX partially rescued the antiproliferation effect of cannabidiol [78]. Similarly, Aviello et al. suggested that cannabidiol reduces the phosphorylation levels of Akt to prevent human colon adenocarcinoma Caco- 2 cells growth. This effect was counteracted by the CB1 receptor antagonists rimonabant and AM251 and the TRPV1 receptor antagonist capsazepine [79]. Noradrenaline has been shown to induce $\mathrm{Ca}^{2+}$ flux by activating alpha 1D-AR and TRPV1 and, subsequently, eliciting the extracellular signal-regulated kinase 1/2 (ERK1/2), PLC, and PKC pathways to promote the proliferation of human prostate tumor PC-3 cells. This effect was completely reversed by alpha 1D-AR/TRPV1 double-knockdown or treatment with a combination of clopenphendioxan and capsazepine [80].

\section{TRPVI agonists affect cell proliferation independently of TRPVI}

Several research groups have reported TRPV1 agonists affecting cell proliferation in a TRPV1independent manner. These agonists perform proliferation functions through two mechanisms. Firstly, the chemicals contribute to antiproliferation; for example, in the study carried out by Zhang et al., capsaicin induced apoptosis by increasing ERK phosphorylation and alleviating STAT3 phosphorylation, thus inhibiting the proliferation of a hepatocellular carcinoma cell line (PLC/PRF/5) cells. This was independent of TRPV1 [81] because no TRPV1 expression was detected in PLC/PRF/ 5 or the other hepatocellular carcinoma cell lines (HuH7 and HepG2) [81]. Capsaicin suppressed prostate cancer androgen-resistant PC-3 cell proliferation by inducing apoptosis via the production of ROS by the mitochondria and a decrease in perturbations in the inner transmembrane potential $(\triangle \Psi \mathrm{m})$, which could not be reversed by capsazepine treatment, indicating TRPV1 was not involved [82]. Capsaicin reduced the proliferation of human pancreatic neuroendocrine tumor BON and QGP-1 cells by disrupting the mitochondrial membrane potential and suppressing ATP synthesis to induce apoptosis, which was unaffected by a reduction in TRPV1 expression levels [83]. Recently, we found that capsaicin inhibited cell proliferation in nasopharyngeal carcinoma (NPC) CNE2 and SUNE1 cells by directly targeting p38, leading to MKK3-p38 axis blockage, in a TRPV1-independent manner [84].

Secondly, the chemicals play vital roles in proliferation by activating receptors other rather than TRPV1. For example, cannabigerol, an agonist of TRPV1, prevented human Caco-2 cells growth by 
increasing CHOP mRNA levels and ROS production to stimulate apoptosis [85]. This effect was alleviated in TRPM8-knockdown cells but not in cells treated with the TRPV1 antagonist ruthenium red [85]. $\mathrm{N}$-arachidonoylethanolamine (anandamide, AEA) inhibited the proliferation of murine neuroblastoma N1E-115 cells, and proliferation was rescued by a lipid raft disruptor, methyl-b-cyclodextrin, but not by the TRPV1 antagonist capsazepine [86].

\section{TRPV1 regulates cell death}

Studies have demonstrated that pathological changes in or the pharmacological regulation of TRPV1 expression levels affect cell death. As mentioned in the previous section, TRPV1 overexpression or agonist treatment induces apoptosis, preventing cancer cell proliferation. Therefore, in this section, we focus on the roles of TRPV1 in cell death and provide a summary of the information (Table 3).

\section{TRPVI expression affects cell death}

In 2018, Yang et al. published a paper in which they described the overexpression of TRPV1 inducing a pro-apoptotic effect mediated by p53 activation [71]. In 2016, Pecze and co-workers demonstrated that the ectopic expression of TRPV1 in human breast cancer MCF-7 cells led to apoptosis [87]. The overexpression of fibulin-5, a multifunctional extracellular matrix (ECM) protein encoded by the FBLN5 gene, induced apoptosis in human colorectal cancer HT-29 and SW480 cells by enhancing the phosphorylation of p38 and ERK and alleviating the level of p-Akt by downregulating TRPV1 [88]. These studies indicate that TRPV1 can promote or inhibit cell death in a cancer- or tissue-specific manner.

\section{TRPVI agonists affect cell death dependent on TRPVI}

Apoptotic or necrotic cell death can be triggered by calcium influx [89]. A large body of evidence shows the $\mathrm{Ca}^{2+}$-channel-activating function of TRPV1 evoked by its agonists is responsible for these chemically induced cell deaths. The overexpression of TRPV1 in human breast cancer MCF-7 cells has been reported to have no effect on cell numbers; however, the increased expression of exogenous TRPV1 meant that necrosis was more effectively induced by the capsaicin activation of TRPV1 and the subsequent upregulation of $c$-Fos and the necrotic marker RIP3 [90]. Arachidonyl ethanolamide induced apoptosis in human uterine cervix cancer C299, Caski, and HeLa cells, and this was reversed by capsazepine [91]. Capsaicin induced apoptosis in human osteosarcoma
G292 cells by activating endoplasmic reticulum TRPV1, which led to cytochrome $C$ release [92]. TRPV1 agonists, capsaicin and MRS1477, stimulated ROS production and mitochondrial membrane depolarization to induce apoptosis, which was blocked by capsazepine [93]. In human endometrial cancer Ishikawa cells, AEA and cannabidiol caused apoptosis by activating TRPV1 to increase intracellular $\mathrm{Ca}^{2+}$ levels [94]. Capsaicin also induced apoptotic and necrotic cell death in human breast cancer SUM149PT cells, and the reduction in cell viability mediated by capsaicin was diminished by capsazepine treatment [68]. Taken together, it appears agonists of TRPV1, such as capsaicin, arachidonyl ethanolamide, MRS1477, AEA and cannabidiol, induce cell death by activating TRPV1 channels.

\section{TRPVI agonists and antagonists affect cell death independently of TRPV 1}

In contrast, several studies have revealed that certain TRPV1 pharmacological regulators trigger cell death independently of TRPV1. For example, the induction of apoptosis in human cutaneous melanoma A375 cells by the TRPV1-activator AEA was completely counteracted by methyl- $\beta$ cyclodextrin, a membrane cholesterol depletory, but not by capsazepine [95]. A similar effect was observed in non-melanoma skin cancer and colorectal cancer [96]. Capsaicin treatment induced apoptosis in methylcholanthrene-induced fibrosarcoma Meth A cells, and this could not be inhibited by the antagonists capsazepine and I-RTX [97]. Capsaicin induced apoptosis in human small cell lung cancer H69, DMS 114, DMS 53, and H82 cells by activating TRPV6 and, subsequently, inducing calpain-1 and calpain-2 activity. However, this pro-apoptotic effect was not abolished by the TRPV1 antagonist SB366791 [98]. Another report showed capsaicin-induced apoptosis in gastric cancer AGS cells was mediated by TRPV6 rather than TRPV1 [99]. Our recent results also indicate that capsaicin promoted apoptosis in NPC CNE2 and SUNE1 cells by inhibiting MKK3-induced p38 activation in a TRPV1-independent manner [84]. $\mathrm{R}(+)$-methanandamide (MA) treatment increased COX-2 and PPARY activity and induced the apoptosis of human cervical carcinoma HeLa cells, an effect that was unaltered by capsazepine [100]. The promotion of necrosis by resiniferatoxin was associated with mitochondrial dysfunction and was not reversed by I-RTX [101]. Furthermore, Gonzales et al. illustrated that both capsaicin and capsazepine induce cell death independently of TRPV1 in oral squamous cell carcinoma HSC3, SCC4, and SCC25 cells [102]. 
Table 3. Role of TRPV1 in Cell Death.

\begin{tabular}{|c|c|c|c|c|c|c|}
\hline Drug & $\begin{array}{l}\text { Dose } \\
(\mu \mathrm{M})\end{array}$ & $\begin{array}{l}\text { Duration } \\
\text { (h) }\end{array}$ & Tissue/cell type & Mechanism & Outcomes & Ref. \\
\hline Capsaicin & 3 & $48 / 96$ & Human breast carcinoma cell line MCF-7 cells & $\begin{array}{l}\text { Activated exogenous TRPV1 and, } \\
\text { subsequently, upregulated } c \text {-Fos and } \\
\text { necrotic marker RIP3 }\end{array}$ & Necrosis & {$[90]$} \\
\hline Capsaicin & 150 & 24 & Human osteosarcoma G292 cells & $\begin{array}{l}\text { Activated endoplasmic reticulum TRPV1 } \\
\text { and induced cytochrome } C \text { release }\end{array}$ & Apoptosis & [92] \\
\hline Capsaicin & 10 & 72 & Human breast cancer MCF-7 cells & $\begin{array}{l}\text { Stimulated ROS production and } \\
\text { mitochondrial membrane depolarization }\end{array}$ & Apoptosis & [93] \\
\hline Capsaicin & 150 & 48 & Human breast cancer SUM149PT cells & Activated TRPV1 & $\begin{array}{l}\text { Apoptosis } \\
\text { Necrosis }\end{array}$ & {$[68]$} \\
\hline Capsaicin & 100 & 72 & $\begin{array}{l}\text { Human Methylcholanthrene-induced fibrosarcoma } \\
\text { Meth A cells }\end{array}$ & $\begin{array}{l}\text { Decreased Fas-associated factor1 (FAF1) } \\
\text { expression level }\end{array}$ & Apoptosis & [97] \\
\hline Capsaicin & 50 & 36 & $\begin{array}{l}\text { Human small cell lung cancer H69, DMS 114, DMS } \\
53 \text {, and H82 cells }\end{array}$ & $\begin{array}{l}\text { Activated TRPV6 and, subsequently, } \\
\text { induced calpain- } 1 \text { and calpain-2 activation }\end{array}$ & Apoptosis & [98] \\
\hline Capsaicin & 50 & $1 / 6 / 24$ & Human gastric cancer AGS cells & $\begin{array}{l}\text { Disrupted mitochondrial integrity, } \\
\text { activated JNK and, thus, led to } \\
\text { TRPV6-mediated p53 stabilization }\end{array}$ & Apoptosis & {$[99]$} \\
\hline Capsaicin & $37.5 / 75$ & $24 / 48$ & $\begin{array}{l}\text { Human nasopharyngeal carcinoma CNE2 and } \\
\text { SUNE1 cells }\end{array}$ & $\begin{array}{l}\text { Inhibited p38 phosphorylation mediated } \\
\text { by MKK3 }\end{array}$ & Apoptosis & {$[84]$} \\
\hline Capsaicin & 150 & 24 & $\begin{array}{l}\text { Human oral squamous cell carcinoma HSC } 3 \text {, SCC4 } \\
\text { and SCC } 25 \text { cells }\end{array}$ & & Cell death & [102] \\
\hline $\begin{array}{l}\text { Arachidonyl } \\
\text { ethanolamide }\end{array}$ & 30 & 48 & $\begin{array}{l}\text { Human uterine cervix cancer C299, Caski, and } \\
\text { HeLa cells }\end{array}$ & Activated TRPV1 & Apoptosis & [91] \\
\hline $\begin{array}{l}\text { Anandamide/ } \\
\text { cannabidiol }\end{array}$ & $50 / 25$ & 48 & Human endometrial cancer Ishikawa cells & $\begin{array}{l}\text { Activated TRPV1 to increase intracellular } \\
\text { calcium levels }\end{array}$ & Apoptosis & [94] \\
\hline Anandamide & 10 & 24 & Human cutaneous melanoma A375 cells & $\begin{array}{l}\text { A complex mechanism comprising CB1 } \\
\text { activation, COX-2, and LOX-derived } \\
\text { product synthesis }\end{array}$ & Apoptosis & [95] \\
\hline Anandamide & 20 & 4 & $\begin{array}{l}\text { The murine squamous carcinoma cell line JWF2 and } \\
\text { human colorectal cancer cell line, HCA-7 Colony } 29\end{array}$ & $\begin{array}{l}\text { Induced oxidative stress and ER-stress } \\
\text { apoptosis }\end{array}$ & Apoptosis & [96] \\
\hline MRS1477 & 2 & 72 & Human breast cancer MCF-7 cells & $\begin{array}{l}\text { Stimulated ROS production and } \\
\text { mitochondrial membrane depolarization }\end{array}$ & Apoptosis & [93] \\
\hline $\begin{array}{l}\mathrm{R}(+) \text {-methanandamide } \\
\text { (MA) }\end{array}$ & 10 & $24-72$ & Human cervical carcinoma HeLa cells & Increased COX-2 expression and activity & Apoptosis & {$[100]$} \\
\hline Resiniferatoxin & 20 & 24 & Human bladder cancer T24 and 5637 cells & Induced mitochondrial dysfunction & Necrosis & [101] \\
\hline Capsazepine & 30 & 24 & $\begin{array}{l}\text { Human oral squamous cell carcinoma HSC } 3 \text {, SCC } 4 \\
\text { and SCC } 25 \text { cells }\end{array}$ & Stimulated ROS production & Apoptosis & [102] \\
\hline
\end{tabular}

\section{TRPV1 regulates cancer metastasis}

Metastasis, which is one of the major causes of cancer-related deaths, requires two early events: migration and invasion [103]. Recently, calcium signaling was found to be closely related to carcinogenesis and metastasis [104-106], yet only a few reports mention the role of TRPV1 in cancer cell metastasis. As TRPV1 serves as the main $\mathrm{Ca}^{2+}$-influx channel, it is reasonable to suggest that TRPV1 could act as an enhancer or inhibitor of migration and invasion in a tissue- or cell-specific manner.

\section{TRPVI agonists and antagonists affect cell migration dependent on TRPVI}

Few published reports describe the direct impact of altering TRPV1 expression on cancer cell metastasis. Most of the studies using agonists or antagonists showed an ambiguous effect of TRPV1 channel activity on migration. On the one hand, Vriens et al. and Waning et al. reported that the activation of TRPV1 can be evoked by hepatocyte growth factor (HGF) and causes the influx of $\mathrm{Ca}^{2+}$ into HepG2 cells following capsaicin treatment, leading to increased cell migration [107, 108]. Another investigation into the pro-migration role of TRPV1 conducted on lymphatic endothelial cells by Nakanishi et al. found TRPV1 functioned as a $\mathrm{pH}$ sensor and was activated by an acidic environment, upregulating the expression of IL-8, and therefore promoting cell migration and invasion [109]. On the other hand, Ramer et al. reported the activation of TRPV1 by MA did not affect cervix adenocarcinoma (HeLa) cell migration but inhibited cell invasion [110]. In addition, a recent study by $\mathrm{Xu}$ et al. focusing on the function of capsaicin in papillary thyroid carcinoma BCPAP cells showed that capsaicin inhibited cell migration in a TRPV1-dependent manner [111]. It is interesting that the activation of TRPV1 can lead to both cell death and increased migration. One possible explanation is that the concentrations of most of the agonists used in the pro-apoptosis/necrosis studies were at micromolar levels, and the treatment duration was usually 24 hours. In contrast, the concentrations of agonists used in the pro-migration studies were at nanomolar levels, or the treatment was provided over a short period (Tables 3 and 4). Although the exact mechanism is unclear, one suggestion is that the treatments differentially altered the levels of $\mathrm{Ca}^{2+}$ influx, which led to opposing effects. 
Table 4. Role of TRPV1 in Metastasis.

\begin{tabular}{|c|c|c|c|c|c|c|}
\hline Drug & Dose & Duration & Tissue/cell type & Mechanism & Outcomes & Ref. \\
\hline Capsaicin & $10 \mu \mathrm{M}$ & $400 \mathrm{~s}$ & Hepatoblastoma HepG2 cell & HGF evoked TRPV1 channel activity, causing $\mathrm{Ca}^{2+}$ influx & $\begin{array}{l}\text { Migration } \\
\uparrow\end{array}$ & [107] \\
\hline Capsaicin & $100 \mathrm{nM}$ & $5 \mathrm{~h}$ & $\begin{array}{l}\text { HGF pretreated hepatoblastoma HepG2 ( } 20 \\
\mathrm{ng} / \mathrm{mL} \text { for } 24 \mathrm{~h} \text { ) cells }\end{array}$ & HGF evoked TRPV1 channel activity, causing $\mathrm{Ca}^{2+}$ influx & $\begin{array}{l}\text { Migration } \\
\uparrow\end{array}$ & [108] \\
\hline Capsaicin & $\begin{array}{l}25 / 50 / 100 \\
\mu \mathrm{M}\end{array}$ & $24 / 48 \mathrm{~h}$ & $\begin{array}{l}\text { Human papillary thyroid carcinoma } \\
\text { BCPAP cells }\end{array}$ & $\begin{array}{l}\text { Capsaicin downregulated Tiwst1, Snail1, MMP2, and } \\
\text { MMP9 and upregulated E-cadherin }\end{array}$ & $\begin{array}{l}\text { Migration } \\
\downarrow \\
\text { Invasion } \downarrow\end{array}$ & [111] \\
\hline Capsaicin & $100 \mu \mathrm{M}$ & $24 \mathrm{~h}$ & Urothelial cancer 5637 cells (null-TRPV1) & $\begin{array}{l}\text { Capsaicin treatment induced more aggressive gene } \\
\text { expression, e.g., MMP1, MMP9, and S100A4 }\end{array}$ & invasion $\uparrow$ & [115] \\
\hline Capsaicin & $\begin{array}{l}25 / 37.5 / 75 \\
\mu \mathrm{M}\end{array}$ & $48 \mathrm{~h}$ & $\begin{array}{l}\text { Human nasopharyngeal carcinoma CNE2 } \\
\text { and SUNE1 cells }\end{array}$ & $\begin{array}{l}\text { Capsaicin directly targeted p38 and blocked the MKK3-p38 } \\
\text { axis }\end{array}$ & $\begin{array}{l}\text { Migration } \\
\downarrow \\
\text { Invasion } \downarrow\end{array}$ & {$[84]$} \\
\hline \multirow[t]{2}{*}{$4 a-P D D$} & $1 \mu \mathrm{M}$ & $5 \mathrm{~h}$ & $\begin{array}{l}\text { HGF pretreated hepatoblastoma HepG2 ( } \\
20 \mathrm{ng} / \mathrm{mL} \text { for } 24 \mathrm{~h} \text { ) cells }\end{array}$ & HGF evoked TRPV1 channel activity, causing $\mathrm{Ca}^{2+}$ influx & $\begin{array}{l}\text { Migration } \\
\uparrow\end{array}$ & [108] \\
\hline & & & $\begin{array}{l}\text { Primary human adult dermal LECs } \\
\text { (HDLECs) incubated with pH-6.4 } \\
\text { starvation medium }\end{array}$ & $\begin{array}{l}\text { Acidic environment elicited TRPV1 activation, which } \\
\text { upregulated IL-8 expression }\end{array}$ & $\begin{array}{l}\text { Migration } \\
\uparrow\end{array}$ & [109] \\
\hline MA & $10 \mu \mathrm{M}$ & $72 \mathrm{~h}$ & Cervix adenocarcinoma HeLa cells & $\begin{array}{l}\text { MA elicited TRPV1 activation and upregulated TIMP-1 } \\
\text { expression via MAPK pathway, causing decrease in MMP2 }\end{array}$ & Invasion $\downarrow$ & [110] \\
\hline Cannabidiol & $3 \mu \mathrm{M}$ & $72 \mathrm{~h}$ & $\begin{array}{l}\text { Human lung cancer A549, H358, and H460 } \\
\text { cells }\end{array}$ & $\begin{array}{l}\text { CBD elicited TRPV1 activation, upregulated ICAM1 } \\
\text { expression via phosphorylating p42/44, and subsequently } \\
\text { upregulated TIMP-1 }\end{array}$ & $\begin{array}{l}\text { Migration } \\
\downarrow \\
\text { Invasion } \downarrow\end{array}$ & [114] \\
\hline AM404 & $5 / 15 / 25 \mu \mathrm{M}$ & $24 \mathrm{~h}$ & Neuroblastoma cells SK-N-SH & $\begin{array}{l}\text { AM404 inhibited NFAT transcriptional activity, thus, } \\
\text { downregulating MMP1, MMP2, and MMP7 }\end{array}$ & $\begin{array}{l}\text { Migration } \\
\downarrow \\
\text { Invasion } \downarrow\end{array}$ & [116] \\
\hline Bortezomib & $10 \mathrm{nM}$ & $24 \mathrm{~h}$ & Osteosarcoma HOS cell & Inhibited TRPV1 degradation & Invasion $\downarrow$ & [117] \\
\hline
\end{tabular}

\section{TRPVI affects cell invasion}

Unlike its effect on migration, the effect of TRPV1 on cancer cell invasion has been relatively well characterized and studied, and TRPV1 is believed to function as an invasion repressor. In 2005, Lazzeri et al. showed TRPV1 protein expression levels in urothelial cancer (UC) progressively decreased over progressive cancer metastasis stages [112]. In the same vein, Kalogris et al. found this reduction to be not only translational but also transcriptional in UC. They also showed TRPV1 expression was positively related to survival rate, suggesting TRPV1 could be used as a factor for estimating the prognosis [113].

Evidence suggests TRPV1 may regulate the ECM, which plays a critical role in cell metastasis [12, 13] and, thus, the regulation of cell invasiveness. Ramer et al. demonstrated that the TRPV1 agonist MA can inhibit cell invasion in HeLa cells by inducing the expression of tissue inhibitor of MMPs (TIMP)-1 and, thereby, downregulating MMP2, in a TRPV1 dependent manner [110]. In a later study, the same group found that intercellular adhesion molecule-1 (ICAM1) was upregulated by cannabidiol-elicited TRPV1-activation-mediated p42/44 activation in lung cancer cell lines A549, H358, and H460, subsequently inhibiting cell invasion [114]. Additionally, Xu et al. showed capsaicin-elicited TRPV1 activation downregulated Twist1, Snail1, MMP2, and MMP9 expression and upregulated E-cadherin expression, thereby inhibiting cell invasion by papillary thyroid carcinoma BCPAP cells [111].

\section{TRPVI agonists and antagonists affect cell migration independently of TRPV 1}

Investigations into TRPV1 commonly focus on the effects of treatment with agonists, e.g., capsaicin and cannabinoids, or antagonists such as capsazepine and AM404. However, the effects on metastasis either from TRPV1 activity alteration or the actions of agonists and antagonists should be interpreted with caution because of the reports of TRPV1 agonists and antagonists regulating cell migration and invasion in a TRPV1-independent manner. For instance, Caprodossi et al. found capsaicin promoted the more aggressive expression of genes, such as MMP1, MMP9, and S100A, and the invasiveness of null-TRPV1 urothelial cancer 5637 cells [115]. Whereas, in NPC, we found capsaicin inhibited cell mobility by blocking MKK3-induced p38 activation in a TRPV1-independent manner [84]. Caballero et al. reported AM404, an antagonist of TRPV1 and CB1, inhibited NFAT transcriptional activity and, thus, downregulated MMP1, MMP2, and MMP7 in neuroblastoma SK-N-SH cells via a mechanism unrelated to TRPV1 [116]. Furthermore, a recent investigation conducted by Punzo et al. reported JWH133 and resiniferatoxin enhanced the antiproliferation, anti-invasion, and apoptosis effects of bortezomib (BTX), a selective, reversible proteasome inhibitor, in osteosarcoma cells. However, this report does not include direct evidence to show if the synergism was exerted by BTX-mediated TRPV1 upregulation or if the TRPV1 upregulation was an unrelated effect of BTX [117]. 
Table 5. Role of TRPV1 in Cancer Therapy.

\begin{tabular}{|c|c|c|c|c|c|c|}
\hline Drug & $\begin{array}{l}\text { Dose } \\
(\mu \mathrm{M})\end{array}$ & $\begin{array}{l}\text { Duration } \\
\text { (h) }\end{array}$ & Tissue/cell type & Mechanism & Outcomes & Ref. \\
\hline Capsaicin & 100 & 24 & $\begin{array}{l}\text { Human hepatocellular } \\
\text { carcinoma PLC/PRF/5 } \\
\text { cells }\end{array}$ & $\begin{array}{l}\text { Induced apoptosis by increasing phosphorylation levels of } \\
\text { ERK and attenuating STAT3 phosphorylation }\end{array}$ & $\begin{array}{l}\text { Increased antitumor } \\
\text { sensitivity of } \\
\text { sorafenib }\end{array}$ & {$[81]$} \\
\hline Capsaicin & 150 & 12 & $\begin{array}{l}\text { Human bladder } \\
\text { transitional cell } \\
\text { carcinoma } 5637 \text { cells }\end{array}$ & Inhibited PCNA translocation to the nucleus & $\begin{array}{l}\text { Increased antitumor } \\
\text { efficacy of } \\
\text { pirarubicin }\end{array}$ & [121] \\
\hline Capsazepine & 10 & 6 & $\begin{array}{l}\text { Human colorectal } \\
\text { cancer HCT116 cells }\end{array}$ & $\begin{array}{l}\text { Mediated induction of expression of death receptors DR4 and } \\
\text { DR5 via ROS-JNK-CHOP pathway, downregulated the } \\
\text { expression of cell survival proteins, and upregulated the } \\
\text { expression of proapoptotic proteins }\end{array}$ & $\begin{array}{l}\text { Increased antitumor } \\
\text { activity of TRAIL }\end{array}$ & [125] \\
\hline $\begin{array}{l}\text { Capsazepine/SB366791/ } \\
\text { AMG9810/BCTC }\end{array}$ & 10 & 0.5 & $\begin{array}{l}\text { Human lung cancer } \\
\text { A549 cells }\end{array}$ & & $\begin{array}{l}\text { Enhanced cell death } \\
\text { induced by } \gamma \text {-rays }\end{array}$ & [118] \\
\hline Alpha-lipoic acid & 50 & 24 & $\begin{array}{l}\text { Human breast } \\
\text { carcinoma cell line } \\
\text { MCF-7 cells }\end{array}$ & Induced apoptosis via activation of TRPV1 & $\begin{array}{l}\text { Increased antitumor } \\
\text { sensitivity of cisplatin }\end{array}$ & {$[120]$} \\
\hline Melatonin & 300 & 2 & $\begin{array}{l}\text { Human breast } \\
\text { carcinoma cell line } \\
\text { MCF-7 cells }\end{array}$ & Increased apoptosis induced by doxorubicin & $\begin{array}{l}\text { Increased antitumor } \\
\text { sensitivity of } \\
\text { doxorubicin }\end{array}$ & [122] \\
\hline Hypericum perforatum & 300 & 24 & $\begin{array}{l}\text { Human breast } \\
\text { carcinoma cell line } \\
\text { MCF-7 cells }\end{array}$ & Downregulated apoptosis induced by 5 -fluorouracil & $\begin{array}{l}\text { Decreased antitumor } \\
\text { sensitivity of } \\
\text { 5-fluorouracil }\end{array}$ & [123] \\
\hline
\end{tabular}

\section{TRPV1 affects cancer therapy}

\section{TRPVI agonists and antagonists affect cancer therapy dependent on TRPVI}

To date, there has been some evidence associating TRPV1 expression with the efficiency of radiotherapy and chemotherapy, and several investigators have published the impact of TRPV1 agonists and antagonists on these treatments. In 2016, Nishino et al. reported that pretreatment with the TRPV1 channel inhibitors capsazepine, SB366791, AMG9810, and BCTC suppressed repair of $\gamma$-ray-induced-DNA-damage in human lung cancer A549 cells, indicating TRPV1 antagonists may serve as radiosensitizers, enhancing the efficacy of radiation therapy [118]. Although there is no strong evidence that these chemicals impact the effectiveness of radiotherapy through TRPV1, Masumoto et al. demonstrated that depletion of TRPV1 suppressed the degree of DNA damage induced by $\gamma$-irradiation and UVB irradiation [119]. Therefore, it is likely TRPV1 is involved in DNA-damage responses induced by radiotherapy. However, not all the effects and mechanisms have been clarified.

There are many pharmacological regulators of TRPV1, and several studies have focused on the roles of TRPV1 agonists/antagonists in chemotherapy (Table 5). The toxicity of cisplatin on breast cancer MCF-7 cells was found to be increased by TRPV1-channel activation by alpha-lipoic acid (ALA), the effect of which was reversed by the TRPV1 blocker capsazepine [120]. Capsaicin increased the antiproliferative effects of pirarubicin, a major drug used in urinary bladder instillation chemotherapy, and the effect was reversed by capsazepine treatment
[121]. In human breast cancer MCF-7 cells, doxorubicin treatment activated TRPV1, resulting in increased intracellular $\mathrm{Ca}^{2+}$, which was reversed by the TRPV1 antagonist melatonin. Furthermore, a combination of doxorubicin and melatonin treatment led to higher apoptosis levels than doxorubicin treatment [122]. TRPV1 was also activated by 5-fluorouracil, inducing apoptosis; however, 5-fluorouracil toxicity was downregulated by the TRPV1-channel inhibitor Hypericum perforatum in breast cancer MCF-7 cells [123]. The TRPV1 agonist resiniferatoxin enhanced the antiproliferation effect of BTX in human osteosarcoma HOS cell lines by aggravating apoptosis [117]. The above-described cases indicate that TRPV1 agonists and chemotherapeutic agents may have synergic effects in cancer therapy. Nevertheless, the roles of TRPV1 antagonists in cancer therapy are controversial.

\section{TRPVI agonists and antagonists affect therapy independently of TRPV 1}

Several reports show that TRPV1 agonists/ antagonists alter the sensitivity of chemotherapeutic agents without stimulating TRPV1. For instance, sorafenib is the standard systemic chemotherapy drug for the treatment of advanced hepatocellular carcinoma [124]; capsaicin enhanced the antitumor sensitivity of sorafenib in hepatocellular carcinoma PLC/PRF/5 cells without obvious TRPV1 expression [81]. Capsazepine amplified the antitumor activity of tumor necrosis factor-related apoptosis-inducing ligand (TRAIL) through multiple mechanisms, including promoting the expression of the death receptors DR4 and DR5 via the ROS-JNK-CHOP pathway; downregulating the expression of cell survival proteins cFLIP, survivin, $\mathrm{Bcl}-\mathrm{xL}, \mathrm{Bcl}-2$, and 
cIAP-1; and upregulating the expression of proapoptotic proteins Bax and p53 [125]. However, these effects did not involve TRPV1 [125].

\section{TRPV1 regulates tumor microenvironment}

Tumors are not just a simple collection of cancerous cells, rather they are a complex of tumor cells and their interactions with the surrounding cells, forming the tumor microenvironment (TME). Recent reviews have indicated TME is an important mediator in cancer progression and is mainly composed of (a) ECM, which provides structural and nutritional support for tumor development; (b) tumor vasculature, which carries oxygen and nutrients to tumor cells and a provides a "highway" for metastasis; (c) cancer-associated fibroblasts, which contribute to tumor proliferation and metastasis, as well as regulating the formation of ECM; and (d) the immune system, which plays a critical part in tumor-related inflammation [126-128]. The contribution of the important intercellular and intracellular messengers, $\mathrm{Ca}^{2+}$ ions, to the TME has been reviewed elsewhere [105, 129-131]. As TRPV1 is a major $\mathrm{Ca}^{2+}$ channel, we summarize the relationships between TRPV1 and TME in the following section.

\section{TRPVI and cancer-associated fibroblasts}

The final outcome of cancer development is not only determined by autonomous cancer cell defects but also by interactions between cancer cells and the TME. Cancer-associated fibroblasts are major components of the tumor stroma, and evidence collated over many years indicates that fibroblasts are key players in cancer development [132, 133]. Cancer-associated fibroblasts (CAF) can be recruited and activated by cancer-secreted growth factors, among which TGF- $\beta$ is the main factor contributing to their activation [134-136].

Associations between TRPV1 and TGF- $\beta$ in somatic cells have been reported for many years. For instance, Bodo et al. demonstrated that the activation of TRPV1 by capsaicin upregulated TGF- $\beta 2$ mRNA and protein expression in human hair follicles through an unknown mechanism [137]. This was supported by further studies, which showed expression of TGF- $\beta 1$ was attenuated in a TRPV1-knock-out animal model [138-140]. These findings hint at the possible regulation of TGF- $\beta$ by TRPV1, yet currently, there is no evidence for correlation or interaction between TRPV1 and TGF- $\beta$ in cancer. As fibroblasts act as important mediators for other TME components [132, 133], it would be interesting to further investigate the relationship between TRPV1 and TGF- $\beta$ in cancer cells and cancer-related fibroblasts.

\section{TRPVI and ECM}

ECM is mainly composed of the basement membrane, which primarily comprises collagen, and the interstitial matrix containing proteoglycans and fibrous proteins [141]. Hence, TRPV1 is a transmembrane protein that functions as a temperature and $\mathrm{pH}$ sensor and a non-selective cation channel; it is unsurprising, therefore, that the ECM and TRPV1 are closely linked. According to previous research, several components of the ECM are able to modulate TRPV1 activity; for instance, extracellular hyaluronan (hyaluronic acid) reduced the excitation of the TRPV1 channel, thereby reducing the activity of peripheral nociceptors [142]. Moreover, another ECM protein, fibulin-5, was reported to induce apoptosis in colorectal cancer cells by downregulating TRPV1 expression [88]. However, TRPV1 is also capable of regulating ECM proteins, including the main regulators of collagen in ECM matrix metalloproteinases (MMPs), which are highly relevant to the metastatic processes of cancer cells [143, 144]. In the immortalized somatic cell, TRPV1 was reported to directly mediate the expression of MMP-1 [145, 146], and Huang et al. further elucidated that TRPV1 regulates MMP1 expression via the $\mathrm{Ca}^{2+}$-ERK pathway [147]. In the field of oncology, there have been several reports showing that TRPV1 activation in cancer cells regulates MMP activity by modulating the expression of TIMP-1 [110, 148]. However, there were no details of the mechanisms and signaling pathways involved in the TRPV1-regulation of TIMP-1 expression, and these should be investigated in the future. Moreover, whether TRPV1 regulates other ECM proteins is unclear.

\section{TRPVI and cancer-associated angiogenesis}

During angiogenesis, new blood vessels emerge from the existing vasculature via sprouting, which is vital for oxygen and nutrient transportation and is implicated in cancer metastasis. As early as 1995, the first links between the regulation of angiogenesis and calcium signaling were discovered by Kohn et al., who reported that carboxyamidotriazole (CAI), a non-voltage-operated $\mathrm{Ca}^{2+}$-channel inhibitor, inhibited vascular tube formation on Matrigel and angiogenesis in vivo [149]. Faehling et al. further suggested that angiogenesis requires $\mathrm{Ca}^{2+}$ influx; vascular endothelial growth factor (VEGF) induced $\mathrm{Ca}^{2+}$ influx into human umbilical vein endothelial cells (HUVEC), and adding CAI inhibited the VEGF-elicited $\mathrm{Ca}^{2+}$ influx, inhibiting endothelial cell proliferation [150]. There are several detailed reviews 
available covering $\mathrm{Ca}^{2+}$ signaling and angiogenesis, which are not elaborated on here [151-153].

The process of angiogenesis requires the proliferation and motility of endothelial cells, in which several critical proteins, i.e., VEGF, EGFR, and fibroblast growth factor, play important roles [132, 154-156]. Among these, VEGF is considered the most potent factor for endothelial cell proliferation and migration. In the context of cancer, VEGF can be released from tumor cells or the tumor-related ECM and binds to VEGFR1/2 to induce the proliferation of vascular endothelial cells [157]. As mentioned above, VEGF is able to induce $\mathrm{Ca}^{2+}$ influx into HUVECs [150]. Indeed, VEGF has recently been reported to mediate $\mathrm{Ca}^{2+}$ influx by transactivating the channel function of TRPV1. In addition, VEGF secreted by human uveal melanoma cells transactivates TRPV1 function, causing intracellular $\mathrm{Ca}^{2+}$ influx into endothelial cells, which is essential for angiogenesis [158]. Interestingly, $\mathrm{Su}$ et al. showed $\mathrm{Ca}^{2+}$ influx by simvastatin elicited TRPV1 activation of the AKT signal, which subsequently activated calcium-calmodulin kinase II (CaMKII) and eNOS, leading to angiogenesis [159]. VEGF transactivation of TRPV1 might share a similar pathway, although more experimental data is needed to support this hypothesis.

Whether TRPV1 activity regulates the expression and function of VEGF and its receptor is still largely unknown; however, hints have been provided by animal models. Vinuesa et al. showed that Trpo1 -/mice were more vulnerable to dextran-sodiumsulfate-induced colon cancer [160]. Their investigation demonstrated that the NF-kB and STAT3 signal pathways were hyperactivated in Trpo1 -/- mice, resulting in the upregulation of a group of inflammatory factors, including IL-1 and IL-6, and invasion factors such as MMP9, which subsequently enhanced the carcinogenesis [160]. NF-kB and STAT3 are known to be regulators of VEGF in several cancers [161-163] and may be involved in the regulation of VEGF expression by TRPV1.

\section{TRPV1 in inflammation and leukocytes}

A considerable fraction of TME components is associated with inflammation and leukocyte activities. Cytokines released from tumor cells and TME components attract immune cells and trigger inflammation. Several systematic reviews have pointed out that inflammation contributes to tumorigenesis and helps to shape tumor progression, and modulating immune factors in the TME is a promising therapeutic approach for cancer treatment [164-166]. The characteristics of inflammation include heat and pain, and, because TRPV1 functions as a nociceptor, it may be highly relevant to this area of research.

TRPV1 is involved in key immune cell functions, and $\mathrm{Ca}^{2+}$ signaling is important for lymphocyte activation and differentiation [167, 168]. The functional expression of TRPV1 in mouse and human CD4+ T-cells was described by Bertin et al., who showed NFAT and NFkB, two key transcription factors of immune cell activation, were less expressed in the nuclear fraction of CD4+ T-cells isolated from Trpo1 knockout mice. This resulted in the reduced production of proinflammatory cytokines and indicated that TRPV1 is necessary for proper downstream T-cell signaling [169]. Moreover, TRPV1 was also shown to be expressed in dendritic cells (DCs), which are pivotal in antigen presentation and lymphocyte activation. Notably, the administration of capsaicin induced the maturation of DCs in Trpv1 +/+ mice but not in Trpv1 -/- mice [170].

TRPV1 was also reported to be a modulator for inflammatory cytokines, although the exact regulatory network for TRPV1-inflammation is unclear. Okada et al. showed the expression of several pro-inflammation cytokines, such as MCP-1 and IL-6, was suppressed during the healing of eye injury in Trpo1 -/- mice, and they suggested that TRPV1 may serve a pro-inflammatory role [138]. However, the story is completely reversed in cancer. In the AOM/DSS-induced colon cancer mouse model, several pro-inflammation factors, including IL-6 and IL-11, were found to be upregulated [160]. Further research demonstrated that Trpv1-deficient mice exhibited hyperactivation of the STAT and NFKB signal pathways; therefore, TRPV1 was believed to exert a protective role in colon cancer [160]. The findings of a recent study by Erin were in line with this view, as they showed the activation of TRPV1 by capsaicin downregulated the expression of TNF-a, IL-6, and IL-10 and suppressed lung metastasis in a breast cancer metastasis mouse model [171]. However, something that should be brought to the reader's attention is that this study did not rule out the possibility that capsaicin functioned independently of TRPV1. Furthermore, because the above results were based on a TRPV1-deficient animal model, the regulation of inflammatory factors was more likely to be an outcome of systematic changes. Whether TRPV1 regulates the secretion of inflammatory cytokines by cancer cells is not fully understood, and the mechanisms need to be further investigated.

\section{Conclusion}

Based on the reviewed evidence, the following conclusions can be drawn. The expression of TRPV1 is 
elevated in many cancers, and its overexpression suppresses cell proliferation in intestinal, melanoma, and pancreatic cancers and induces apoptosis in melanoma and breast cancers. These findings support the hypothesis that TRPV1 is a tumor-suppressor gene. However, TRPV1 either promotes or inhibits cell death, depending on cancer cell type, implying it has cancer- or tissue-specific functions. Further investigations and experimentations are strongly recommended.

From the current clinical and experimental data, it is likely that TRPV1 serves as a repressor of metastasis, which is in line with its tumorsuppressing role. Whereas the data showing TRPV1 to be a pro-metastasis factor suggest the role of TRPV1 in metastasis may be context-dependent.

As we mentioned, numerous studies have revealed that TRPV1 agonists/antagonists affect cancer proliferation, cell death, and metastasis by activating TRPV1 channels and subsequently increasing the levels of intracellular $\mathrm{Ca}^{2+}$. However, the effects are complex and are determined by the concentration used and treatment duration. Additionally, agonists or antagonists may activate other receptors and, therefore, function in a TRPV1-independent manner. Thus, the effects and mechanisms are unclear, and further studies using combined gene silencing or knockout approaches are needed.
In cancer chemotherapy, the TRPV1 agonist capsaicin has a synergic effect with cisplatin. Nevertheless, capsaicin cannot be systemically administered in large doses, as it induces acute pain and neurological inflammation. In short, current evidence indicates TRPV1 plays certain roles in shaping the TME. However, the signaling networks interacting with TRPV1 have not been fully characterized, and the relationships between TRPV1 and TME need to be further explored. The effects of TRPV1 on cancer cell proliferation, cell death, migration, and invasion, as well as on radiotherapy and chemotherapy, are summarized in Figure 1. Moreover, the TRPV1 signaling pathways in cancer cell proliferation, cell death, migration, and invasion described in this review are summarized in Figure 2. The association between TRPV1 and TME are summarized in Figure 3.

Finally, a number of important issues need to be considered. Given the fact that TRPV1 also plays several intracellular roles, it remains unclear whether TRPV1 functions independently of its channel activity in cancer progression. Further research with more focus on the role of the TRPV1 gene in tumorigenesis and development using gene overexpression and knockdown (knockout) approaches is therefore suggested.

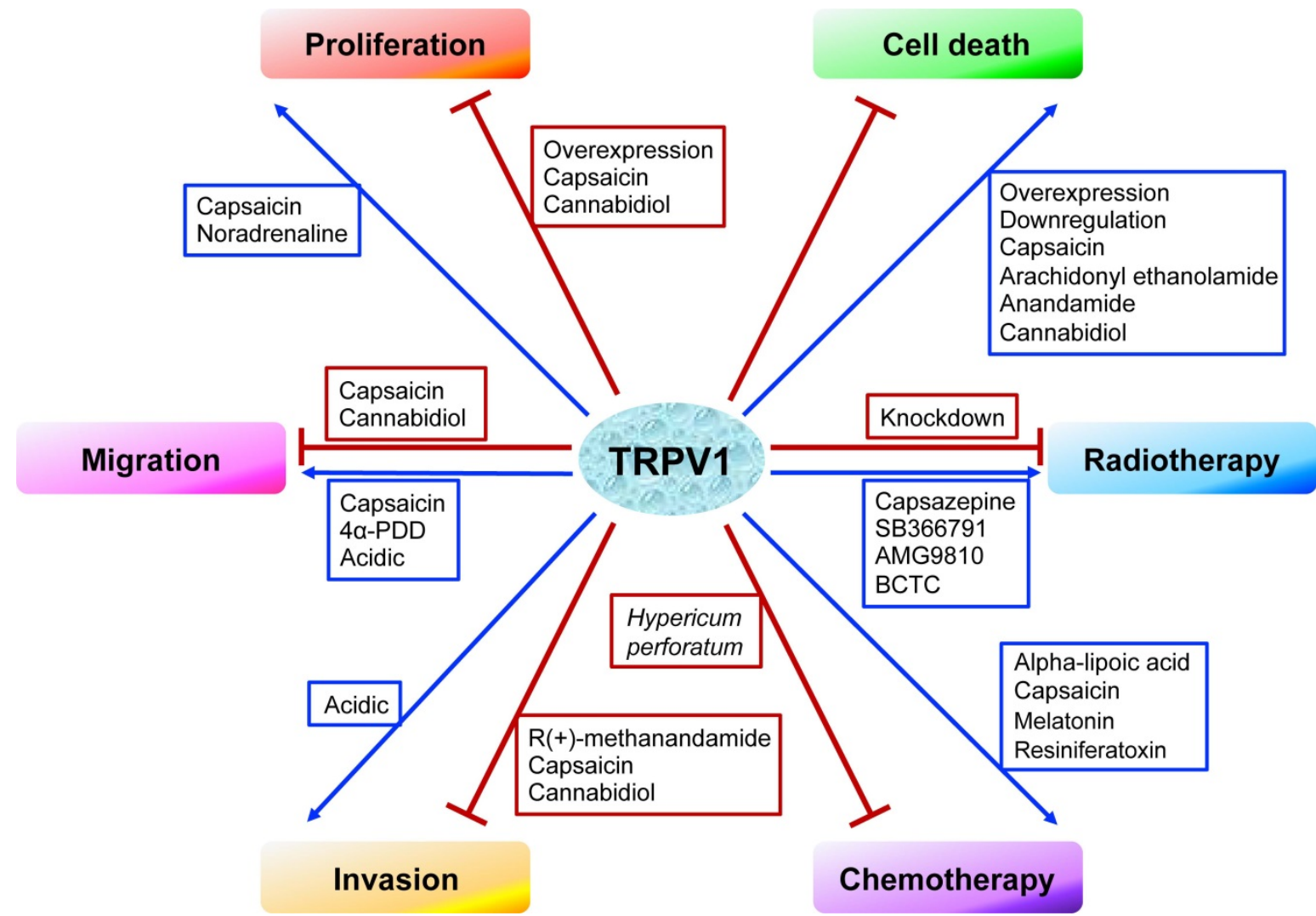

Figure 1. The effects of TRPVI on cancer cell proliferation, cell death, migration, invasion, radiotherapy, and chemotherapy. 


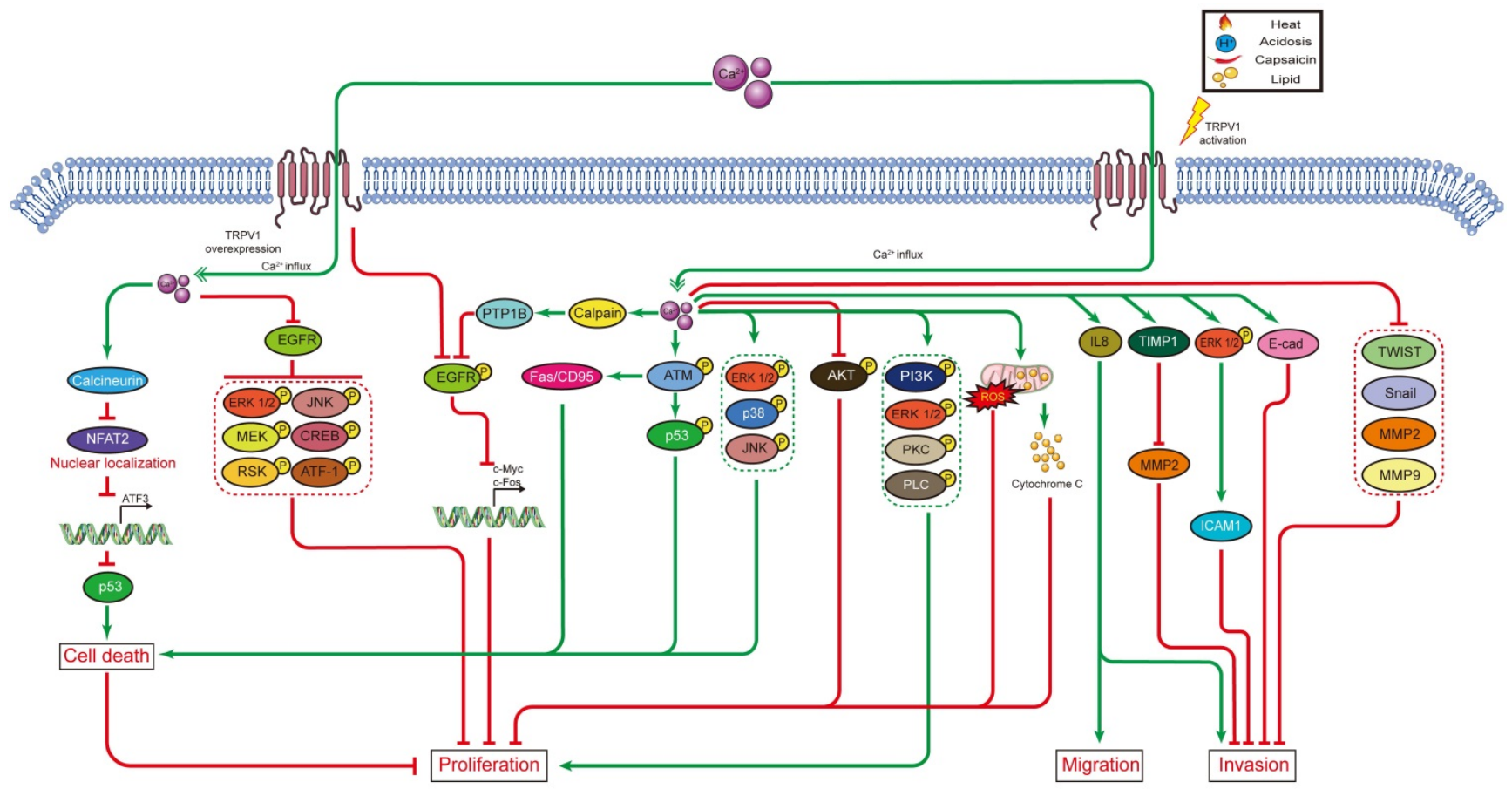

Figure 2. TRPVI signaling pathways in cancer cell proliferation, cell death, migration, and invasion.

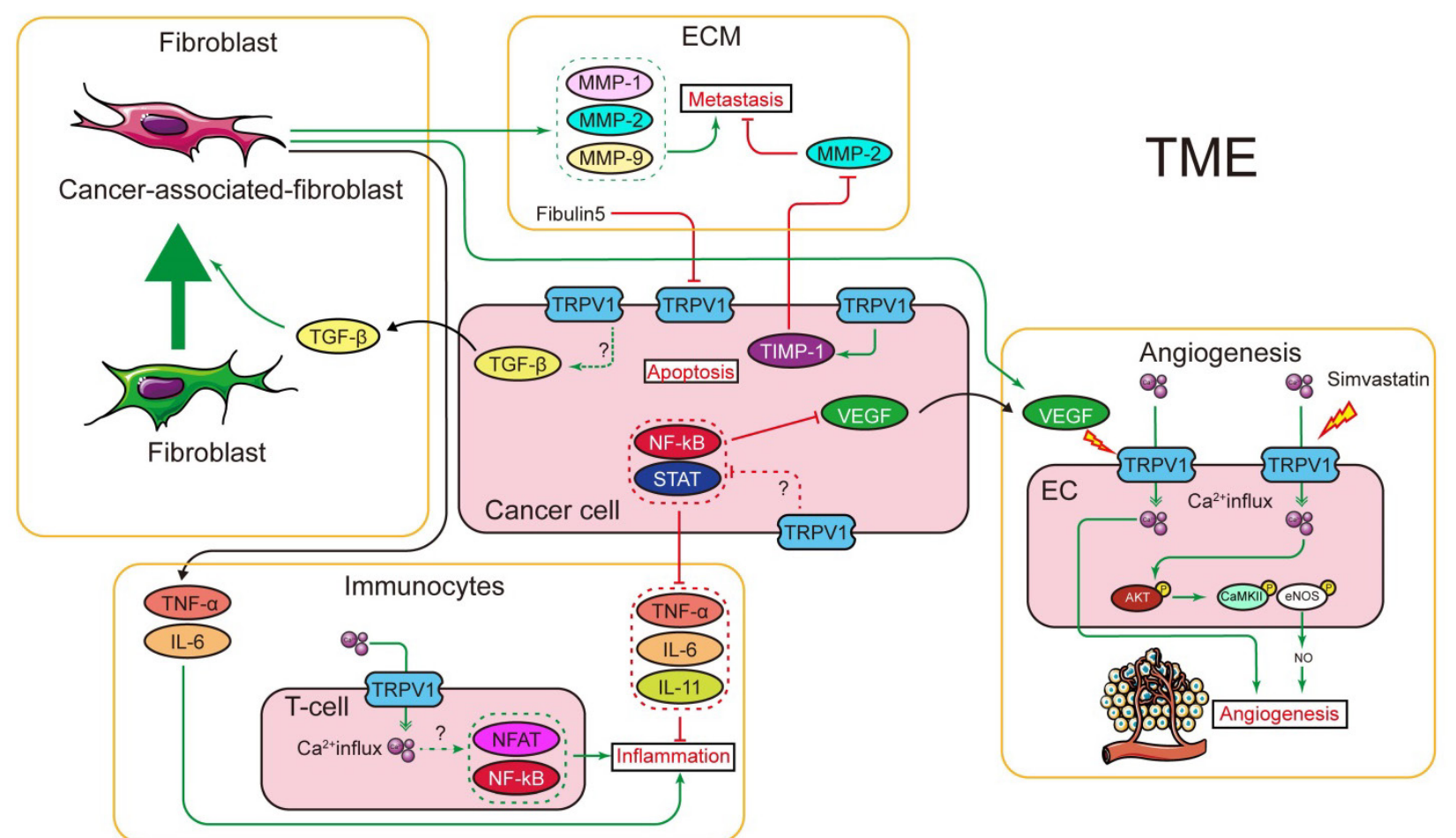

Figure 3. Interaction between TRPV1 and tumor microenvironment. Using transgenic mice, TRPV1 was shown to regulate TGF- $\beta$, which is the major factor that activates fibroblasts and transforms the fibroblasts into CAF. The CAF can secret several cytokines and factors, most of which are TME components, e.g., MMPs (regulates collagen in ECM), TNF- $\alpha$ and IL- 6 (trigger inflammation), and VEGF (promotes angiogenesis). In cancer cells, TRPVI was shown to regulate the expression of several inflammation factors, probably through NFKB and STAT signaling pathways. In immunocytes, TRPV1 is important for T-cell signal transduction. Additionally, TRPV1 can regulate the ECM by promoting TIMP-1 expression. In turn, fibulin 5, an ECM component, downregulates TRPV1 expression in cancer cells. Furthermore, TRPV1 was shown to promote angiogenesis by mediating $\mathrm{Ca}^{2+}$ influx and, subsequently, activating the AKT-CaMKII-eNOS signal pathway. The TRPVI channel function can also be elicited by VEGF, but it is unclear if it shares the same downstream signal. 


\section{Abbreviations}

TRPV1: transient receptor potential cation channel subfamily $\mathrm{V}$, member 1 ; TRP: transient receptor potential; VR1: vanilloid receptor 1; EGFR: epidermal growth factor receptor; PLC: phospholipase C; $\mathrm{PIP}_{2}$ : phosphatidylinositol-4,5bisphosphate; DAG: diacylglycerol; $\mathrm{IP}_{3}$ : inositol triphosphate; PTP1B: protein tyrosine phosphatase 1B; AR: androgen receptor; I-RTX: 5-iodoresiniferatoxin; ESCC: esophageal squamous cell carcinoma; ERK: extracellular signal-regulated kinase; NPC: nasopharyngeal carcinoma; AEA: anandamide; FAF1: Fas-associated factor1; ECM: extracellular matrix; MA: R(+)-methanandamide; HGF: hepatocyte growth factor; UC: urothelial cancer; ICAM1: intercellular adhesion molecule-1; BTX: bortezomib; ALA: alpha-lipoic acid; TRAIL: tumor necrosis factor-related apoptosis-inducing ligand; TME: tumor microenvironment; MMP: matrix metalloproteinase; CAF: Cancer associated fibroblasts; DC: dendritic cell; CAI: carboxyamidotriazole; VEGF: vascular endothelial growth factor; CaMKII: calciumcalmodulin kinase II; HUVEC: human umbilical vein endothelial cell; FGF: fibroblast growth factor.

\section{Acknowledgements}

This study was supported by grants from the National Natural Science Foundation of China (81802280, 81372149), the Natural Science Foundation of Guangdong Province (2021A1515011046, 2019A1515010210), and the Shenzhen Municipal Government of China (JCYJ20180507182427559, GJHZ20180418190559891). Guangdong Provincial Science and Technology Program (No. 2019B030301009). Shenzhen Key Medical Discipline Construction Fund (No. SZXK060). SZU Top Ranking Project (86000000210).

The authors would like to thank Dr. Jessica Tamanini for editing the manuscript prior to submission. They also thank the members of the Instrumental Analysis Center of Shenzhen University for their support.

\section{Authors' contributions}

LL and DZ provided the idea. LL and CC wrote the article. DZ revised the article. CYJ, TX, YCC, and YXZ made suggestions for the article. All authors reviewed the manuscript and approved the final manuscript.

\section{Competing Interests}

The authors have declared that no competing interest exists.

\section{References}

1. Ramsey IS, Delling M, Clapham DE. An introduction to TRP channels. Annu Rev Physiol. 2006; 68: 619-47.

2. Nilius B, Owsianik G, Voets T, Peters JA. Transient receptor potential cation channels in disease. Physiol Rev. 2007; 87: 165-217.

3. Shapovalov G, Ritaine A, Skryma R, Prevarskaya N. Role of TRP ion channels in cancer and tumorigenesis. Semin Immunopathol. 2016; 38: 357-69.

4. Zhai K, Liskova A, Kubatka P, Busselberg D. Calcium Entry through TRPV1: A Potential Target for the Regulation of Proliferation and Apoptosis in Cancerous and Healthy Cells. Int J Mol Sci. 2020; 21.

5. So CL, Milevskiy MJG, Monteith GR. Transient receptor potential cation channel subfamily V and breast cancer. Lab Invest. 2020; 100: 199-206.

6. Bevan S, Quallo T, Andersson DA. Trpv1. Handb Exp Pharmacol. 2014; 222: 207-45.

7. Kedei N, Szabo T, Lile JD, Treanor JJ, Olah Z, Iadarola MJ, et al. Analysis of the native quaternary structure of vanilloid receptor 1 . J Biol Chem. 2001; 276: 28613-9.

8. Caterina MJ, Schumacher MA, Tominaga M, Rosen TA, Levine JD, Julius D. The capsaicin receptor: a heat-activated ion channel in the pain pathway. Nature. 1997; 389: 816-24.

9. Tominaga M, Caterina MJ, Malmberg AB, Rosen TA, Gilbert H, Skinner K, et al. The cloned capsaicin receptor integrates multiple pain-producing stimuli. Neuron. 1998; 21: 531-43.

10. Harteneck C, Plant TD, Schultz G. From worm to man: three subfamilies of TRP channels. Trends Neurosci. 2000; 23: 159-66.

11. Helliwell RJ, McLatchie LM, Clarke M, Winter J, Bevan S, McIntyre P. Capsaicin sensitivity is associated with the expression of the vanilloid (capsaicin) receptor (VR1) mRNA in adult rat sensory ganglia. Neurosci Lett. 1998; 250: 177-80.

12. Patapoutian A, Tate S, Woolf CJ. Transient receptor potential channels: targeting pain at the source. Nat Rev Drug Discov. 2009; 8: 55-68.

13. Kark T, Bagi Z, Lizanecz E, Pasztor ET, Erdei N, Czikora A, et al Tissue-specific regulation of microvascular diameter: opposite functional roles of neuronal and smooth muscle located vanilloid receptor-1. Mol Pharmacol. 2008; 73: 1405-12.

14. Cavanaugh DJ, Chesler AT, Jackson AC, Sigal YM, Yamanaka H, Grant R, et al. Trpv1 reporter mice reveal highly restricted brain distribution and functional expression in arteriolar smooth muscle cells. J Neurosci. 2011; 31: 5067-77.

15. Birder LA, Nakamura Y, Kiss S, Nealen ML, Barrick S, Kanai AJ, et al. Altered urinary bladder function in mice lacking the vanilloid receptor TRPV1. Nat Neurosci. 2002; 5: 856-60.

16. Jordt SE, Tominaga M, Julius D. Acid potentiation of the capsaicin receptor determined by a key extracellular site. Proc Natl Acad Sci U S A. 2000; 97 : 8134-9.

17. Olah Z, Szabo T, Karai L, Hough C, Fields RD, Caudle RM, et al. Ligand-induced dynamic membrane changes and cell deletion conferred by vanilloid receptor 1. J Biol Chem. 2001; 276: 11021-30.

18. Karai L, Brown DC, Mannes AJ, Connelly ST, Brown J, Gandal M, et al. Deletion of vanilloid receptor 1-expressing primary afferent neurons for pain control. J Clin Invest. 2004; 113: 1344-52.

19. Pecze L, Blum W, Henzi T, Schwaller B. Endogenous TRPV1 stimulation leads to the activation of the inositol phospholipid pathway necessary for sustained $\mathrm{Ca}(2+)$ oscillations. Biochim Biophys Acta. 2016; 1863: 2905-15.

20. Pecze L, Viskolcz B, Olah Z. Molecular Surgery Concept from Bench to Bedside: A Focus on TRPV1+ Pain-Sensing Neurons. Front Physiol. 2017; 8: 378.

21. Brito R, Sheth S, Mukherjea D, Rybak LP, Ramkumar V. TRPV1: A Potential Drug Target for Treating Various Diseases. Cells. 2014; 3: 517-45.

22. Feketa VV, Marrelli SP. Induction of therapeutic hypothermia by pharmacological modulation of temperature-sensitive TRP channels: theoretical framework and practical considerations. Temperature (Austin). 2015; 2: 244-57

23. Basith S, Cui M, Hong S, Choi S. Harnessing the Therapeutic Potential of Capsaicin and Its Analogues in Pain and Other Diseases. Molecules. 2016; 21.

24. Garami A, Shimansky YP, Rumbus Z, Vizin RCL, Farkas N, Hegyi J, et al. Hyperthermia induced by transient receptor potential vanilloid-1 (TRPV1) antagonists in human clinical trials: Insights from mathematical modeling and meta-analysis. Pharmacol Ther. 2020; 208: 107474.

25. Zygmunt PM, Petersson J, Andersson DA, Chuang H, Sorgard M, Di Marzo V, et al. Vanilloid receptors on sensory nerves mediate the vasodilator action of anandamide. Nature. 1999; 400: 452-7.

26. Huang SM, Bisogno T, Trevisani M, Al-Hayani A, De Petrocellis L, Fezza F, et al. An endogenous capsaicin-like substance with high potency at recombinant and native vanilloid VR1 receptors. Proc Natl Acad Sci U S A. 2002; 99: 8400-5.

27. Chu CJ, Huang SM, De Petrocellis L, Bisogno T, Ewing SA, Miller JD, et al. $\mathrm{N}$-oleoyldopamine, a novel endogenous capsaicin-like lipid that produces hyperalgesia. J Biol Chem. 2003; 278: 13633-9.

28. Hwang SW, Cho H, Kwak J, Lee SY, Kang CJ, Jung J, et al. Direct activation of capsaicin receptors by products of lipoxygenases: endogenous capsaicin-like substances. Proc Natl Acad Sci U S A. 2000; 97: 6155-60.

29. Ahern GP. Activation of TRPV1 by the satiety factor oleoylethanolamide. J Biol Chem. 2003; 278: 30429-34. 
30. Ambrosino P, Soldovieri MV, Russo C, Taglialatela M. Activation and desensitization of TRPV1 channels in sensory neurons by the PPARalpha agonist palmitoylethanolamide. Br J Pharmacol. 2013; 168: 1430-44.

31. Nieto-Posadas A, Jara-Oseguera A, Rosenbaum T. TRP channel gating physiology. Curr Top Med Chem. 2011; 11: 2131-50.

32. Nersesyan Y, Demirkhanyan L, Cabezas-Bratesco D, Oakes V, Kusuda R, Dawson $\mathrm{T}$, et al. Oxytocin Modulates Nociception as an Agonist of Pain-Sensing TRPV1. Cell Rep. 2017; 21: 1681-91.

33. $\mathrm{Hu} \mathrm{HZ}, \mathrm{Gu} \mathrm{Q}$, Wang C, Colton CK, Tang J, Kinoshita-Kawada M, et al. 2-aminoethoxydiphenyl borate is a common activator of TRPV1, TRPV2, and TRPV3. J Biol Chem. 2004; 279: 35741-8.

34. Martin E, Dahan D, Cardouat G, Gillibert-Duplantier J, Marthan R, Savineau $\mathrm{JP}$, et al. Involvement of TRPV1 and TRPV4 channels in migration of rat pulmonary arterial smooth muscle cells. Pflugers Arch. 2012; 464: 261-72.

35. Bohlen CJ, Priel A, Zhou S, King D, Siemens J, Julius D. A bivalent tarantula toxin activates the capsaicin receptor, TRPV1, by targeting the outer pore domain. Cell. 2010; 141: 834-45.

36. McNamara FN, Randall A, Gunthorpe MJ. Effects of piperine, the pungent component of black pepper, at the human vanilloid receptor (TRPV1). Br J Pharmacol. 2005; 144: 781-90.

37. Szallasi A, Blumberg PM. Resiniferatoxin, a phorbol-related diterpene, acts as an ultrapotent analog of capsaicin, the irritant constituent in red pepper. Neuroscience. 1989; 30: 515-20.

38. Liu L, Welch JM, Erickson RP, Reinhart PH, Simon SA. Different responses to repeated applications of zingerone in behavioral studies, recordings from intact and cultured TG neurons, and from VR1 receptors. Physiol Behav. 2000; 69: 177-86.

39. Pearce LV, Petukhov PA, Szabo T, Kedei N, Bizik F, Kozikowski AP, et al. Evodiamine functions as an agonist for the vanilloid receptor TRPV1. Org Biomol Chem. 2004; 2: 2281-6.

40. Bisogno T, Hanus L, De Petrocellis L, Tchilibon S, Ponde DE, Brandi I, et al. Molecular targets for cannabidiol and its synthetic analogues: effect on vanilloid VR1 receptors and on the cellular uptake and enzymatic hydrolysis of anandamide. Br J Pharmacol. 2001; 134: 845-52.

41. De Petrocellis L, Vellani V, Schiano-Moriello A, Marini P, Magherini PC, Orlando $\mathrm{P}$, et al. Plant-derived cannabinoids modulate the activity of transient receptor potential channels of ankyrin type-1 and melastatin type-8. J Pharmacol Exp Ther. 2008; 325: 1007-15.

42. Andre E, Campi B, Trevisani M, Ferreira J, Malheiros A, Yunes RA, et al. Pharmacological characterisation of the plant sesquiterpenes polygodial and drimanial as vanilloid receptor agonists. Biochem Pharmacol. 2006; 71: $1248-54$

43. Siemens J, Zhou S, Piskorowski R, Nikai T, Lumpkin EA, Basbaum AI, et al. Spider toxins activate the capsaicin receptor to produce inflammatory pain. Nature. 2006; 444: 208-12.

44. Ann J, Kim HS, Thorat SA, Kim H, Ha HJ, Choi K, et al. Discovery of Nonpungent Transient Receptor Potential Vanilloid 1 (TRPV1) Agonist as Strong Topical Analgesic. J Med Chem. 2020; 63: 418-24.

45. Neacsu C, Babes A. The M-channel blocker linopirdine is an agonist of the capsaicin receptor TRPV1. J Pharmacol Sci. 2010; 114: 332-40.

46. Park CK, Xu ZZ, Liu T, Lu N, Serhan CN, Ji RR. Resolvin D2 is a potent endogenous inhibitor for transient receptor potential subtype V1/A1, inflammatory pain, and spinal cord synaptic plasticity in mice: distinct roles of resolvin D1, D2, and E1. J Neurosci. 2011; 31: 18433-8.

47. Chakraborty S, Elvezio V, Kaczocha M, Rebecchi M, Puopolo M. Presynaptic inhibition of transient receptor potential vanilloid type 1 (TRPV1) receptors by noradrenaline in nociceptive neurons. J Physiol. 2017; 595: 2639-60.

48. Dickenson AH, Dray A. Selective antagonism of capsaicin by capsazepine: evidence for a spinal receptor site in capsaicin-induced antinociception. Br J Pharmacol. 1991; 104: 1045-9.

49. Seabrook GR, Sutton KG, Jarolimek W, Hollingworth GJ, Teague S, Webb J, et al. Functional properties of the high-affinity TRPV1 (VR1) vanilloid receptor antagonist (4-hydroxy-5-iodo-3-methoxyphenylacetate iodo-resiniferatoxin. J Pharmacol Exp Ther. 2002; 303: 1052-60.

50. Uslusoy F, Naziroglu M, Cig B. Inhibition of the TRPM2 and TRPV1 Channels through Hypericum perforatum in Sciatic Nerve Injury-induced Rats Demonstrates their Key Role in Apoptosis and Mitochondrial Oxidative Stress of Sciatic Nerve and Dorsal Root Ganglion. Front Physiol. 2017; 8: 335

51. Wiskur BJ, Tyler K, Campbell-Dittmeyer K, Chaplan SR, Wickenden AD, Greenwood-Van Meerveld B. A novel TRPV1 receptor antagonist JNJ-17203212 attenuates colonic hypersensitivity in rats. Methods Find Exp Clin Pharmacol. 2010; 32: 557-64.

52. Valenzano KJ, Grant ER, Wu G, Hachicha M, Schmid L, Tafesse L, et al $\mathrm{N}$-(4-tertiarybutylphenyl)-4-(3-chloropyridin-2-yl)tetrahydropyrazine $-1(2 \mathrm{H})$-carbox-amide (BCTC), a novel, orally effective vanilloid receptor 1 antagonist with analgesic properties: I in vitro characterization and pharmacokinetic properties. J Pharmacol Exp Ther. 2003; 306: 377-86.

53. Toth A, Kedei N, Szabo T, Wang Y, Blumberg PM. Thapsigargin binds to and inhibits the cloned vanilloid receptor-1. Biochem Biophys Res Commun. 2002; 293: 777-82.

54. Dessaint J, Yu W, Krause JE, Yue L. Yohimbine inhibits firing activities of rat dorsal root ganglion neurons by blocking $\mathrm{Na}+$ channels and vanilloid VR1 receptors. Eur J Pharmacol. 2004; 485: 11-20.
55. Jakab B, Helyes Z, Varga A, Bolcskei K, Szabo A, Sandor $K$, et al. Pharmacological characterization of the TRPV1 receptor antagonist JYL1421 (SC0030) in vitro and in vivo in the rat. Eur J Pharmacol. 2005; 517: 35-44.

56. Pradhananga S, Shim WS. Caffeic acid exhibits anti-pruritic effects by inhibition of multiple itch transmission pathways in mice. Eur J Pharmacol. 2015; 762: 313-21.

57. Lee JH, Choi CS, Bae IH, Choi JK, Park YH, Park M. A novel, topical, nonsteroidal, TRPV1 antagonist, PAC-14028 cream improves skin barrier function and exerts anti-inflammatory action through modulating epidermal differentiation markers and suppressing Th2 cytokines in atopic dermatitis. J Dermatol Sci. 2018

58. Gunthorpe MJ, Rami HK, Jerman JC, Smart D, Gill CH, Soffin EM, et al. Identification and characterisation of SB-366791, a potent and selective vanilloid receptor (VR1/TRPV1) antagonist. Neuropharmacology. 2004; 46: 133-49.

59. Voight EA, Gomtsyan AR, Daanen JF, Perner RJ, Schmidt RG, Bayburt EK, et al. Discovery of (R)-1-(7-chloro-2,2-bis(fluoromethyl)chroman-4-yl)-3(3-methylisoquinolin-5-yl)ur ea (A-1165442): a temperature-neutral transient receptor potential vanilloid-1 (TRPV1) antagonist with analgesic efficacy. J Med Chem. 2014; 57: 7412-24

60. Gavva NR, Tamir R, Ou Y, Klionsky L, Zhang TJ, Immke D, et al. AMG 9810 [(E)-3-(4-t-butylphenyl)-N-(2,3-dihydrobenzo[b][1,4] dioxin-6-yl)acrylamide], a novel vanilloid receptor 1 (TRPV1) antagonist with antihyperalgesic properties. J Pharmacol Exp Ther. 2005; 313: 474-84.

61. Kitaguchi T, Swartz KJ. An inhibitor of TRPV1 channels isolated from funnel Web spider venom. Biochemistry. 2005; 44: 15544-9.

62. Moran MM, McAlexander MA, Biro T, Szallasi A. Transient receptor potential channels as therapeutic targets. Nat Rev Drug Discov. 2011; 10: 601-20.

63. Brederson JD, Kym PR, Szallasi A. Targeting TRP channels for pain relief. Eur J Pharmacol. 2013; 716: 61-76.

64. Stock K, Kumar I, Synowitz M, Petrosino S, Imperatore R, Smith ES, et al. Neural precursor cells induce cell death of high-grade astrocytomas through stimulation of TRPV1. Nat Med. 2012; 18: 1232-8.

65. Hartel M, di Mola FF, Selvaggi F, Mascetta G, Wente MN, Felix K, et al. Vanilloids in pancreatic cancer: potential for chemotherapy and pain management. Gut. 2006; 55: 519-28.

66. Marincsak R, Toth BI, Czifra G, Marton I, Redl P, Tar I, et al. Increased expression of TRPV1 in squamous cell carcinoma of the human tongue. Oral Dis. 2009; 15: 328-35.

67. Czifra G, Varga A, Nyeste K, Marincsak R, Toth BI, Kovacs I, et al. Increased expressions of cannabinoid receptor-1 and transient receptor potential vanilloid-1 in human prostate carcinoma. J Cancer Res Clin Oncol. 2009; 135: $507-14$.

68. Weber LV, Al-Refae K, Wolk G, Bonatz G, Altmuller J, Becker C, et al. Expression and functionality of TRPV1 in breast cancer cells. Breast Cancer (Dove Med Press). 2016; 8: 243-52.

69. Roderick HL, Cook SJ. Ca2+ signalling checkpoints in cancer: remodelling $\mathrm{Ca} 2+$ for cancer cell proliferation and survival. Nat Rev Cancer. 2008; 8: $361-75$.

70. de Jong PR, Takahashi N, Harris AR, Lee J, Bertin S, Jeffries J, et al. Ion channel TRPV1-dependent activation of PTP1B suppresses EGFR-associated intestinal tumorigenesis. J Clin Invest. 2014; 124: 3793-806.

71. Yang Y, Guo W, Ma J, Xu P, Zhang W, Guo S, et al. Downregulated TRPV1 Expression Contributes to Melanoma Growth via the Calcineurin-ATF3-p53 Pathway. J Invest Dermatol. 2018; 138: 2205-15.

72. Huang J, Liu J, Qiu L. Transient receptor potential vanilloid 1 promotes EGFR ubiquitination and modulates EGFR/MAPK signalling in pancreatic cancer cells. Cell Biochem Funct. 2020.

73. Bode AM, Cho YY, Zheng D, Zhu F, Ericson ME, Ma WY, et al. Transient receptor potential type vanilloid 1 suppresses skin carcinogenesis. Cancer Res. 2009; 69: 905-13

74. Amantini C, Ballarini P, Caprodossi S, Nabissi M, Morelli MB, Lucciarini R, et al. Triggering of transient receptor potential vanilloid type 1 (TRPV1) by capsaicin induces Fas/CD95-mediated apoptosis of urothelial cancer cells in an ATM-dependent manner. Carcinogenesis. 2009; 30: 1320-9.

75. Liu T, Wang G, Tao H, Yang Z, Wang Y, Meng Z, et al. Capsaicin mediates caspases activation and induces apoptosis through P38 and JNK MAPK pathways in human renal carcinoma. BMC Cancer. 2016; 16: 790.

76. Malagarie-Cazenave S, Olea-Herrero N, Vara D, Diaz-Laviada I. Capsaicin, a component of red peppers, induces expression of androgen receptor via PI3K and MAPK pathways in prostate LNCaP cells. FEBS Lett. 2009; 583: 141-7.

77. Huang R, Wang F, Yang Y, Ma W, Lin Z, Cheng N, et al. Recurrent activations of transient receptor potential vanilloid-1 and vanilloid-4 promote cellular proliferation and migration in esophageal squamous cell carcinoma cells. FEBS Open Bio. 2019; 9: 206-25.

78. Ligresti A, Moriello AS, Starowicz K, Matias I, Pisanti S, De Petrocellis L, et al. Antitumor activity of plant cannabinoids with emphasis on the effect of cannabidiol on human breast carcinoma. J Pharmacol Exp Ther. 2006; 318: 1375-87.

79. Aviello G, Romano B, Borrelli F, Capasso R, Gallo L, Piscitelli F, et al. Chemopreventive effect of the non-psychotropic phytocannabinoid cannabidiol on experimental colon cancer. J Mol Med (Berl). 2012. 90: 925-34.

80. Morelli MB, Amantini C, Nabissi M, Liberati S, Cardinali C, Farfariello V, et al. Cross-talk between alpha1D-adrenoceptors and transient receptor potential 
vanilloid type 1 triggers prostate cancer cell proliferation. BMC Cancer. 2014; 14: 921.

81. Zhang S-s, Ni Y-h, Zhao C-r, Qiao Z, Yu H-x, Wang L-y, et al. Capsaicin enhances the antitumor activity of sorafenib in hepatocellular carcinoma cells and mouse xenograft tumors through increased ERK signaling. Acta Pharmacologica Sinica. 2017; 39: 438-48.

82. Sanchez AM, Sanchez MG, Malagarie-Cazenave S, Olea N, Diaz-Laviada I. Induction of apoptosis in prostate tumor PC-3 cells and inhibition of xenograft prostate tumor growth by the vanilloid capsaicin. Apoptosis. 2006; 11: 89-99.

83. Skrzypski M, Sassek M, Abdelmessih S, Mergler S, Grotzinger C, Metzke D, et al. Capsaicin induces cytotoxicity in pancreatic neuroendocrine tumor cells via mitochondrial action. Cell Signal. 2014; 26: 41-8.

84. Chiang C, Zhang M, Wang D, Xiao T, Zhu L, Chen K, et al. Therapeutic potential of targeting MKK3-p38 axis with Capsaicin for Nasopharyngeal Carcinoma. Theranostics. 2020; 10: 7906-20.

85. Borrelli F, Pagano E, Romano B, Panzera S, Maiello F, Coppola D, et al. Colon carcinogenesis is inhibited by the TRPM8 antagonist cannabigerol, a Cannabis-derived non-psychotropic cannabinoid. Carcinogenesis. 2014; 35: 2787-97.

86. Hamtiaux L, Hansoulle L, Dauguet N, Muccioli GG, Gallez B, Lambert DM. Increasing antiproliferative properties of endocannabinoids in N1E-115 neuroblastoma cells through inhibition of their metabolism. PLoS One. 2011; 6: e26823.

87. Pecze L, Josvay K, Blum W, Petrovics G, Vizler C, Olah Z, et al. Activation of endogenous TRPV1 fails to induce overstimulation-based cytotoxicity in breast and prostate cancer cells but not in pain-sensing neurons. Biochim Biophys Acta. 2016; 1863: 2054-64.

88. Chen Y, Li J, Jin L, Lei K, Liu H, Yang Y. Fibulin-5 contributes to colorectal cancer cell apoptosis via the ROS/MAPK and Akt signal pathways by downregulating transient receptor potential cation channel subfamily V member 1. J Cell Biochem. 2019; 120: 17838-46.

89. Orrenius S, Zhivotovsky B, Nicotera P. Regulation of cell death: the calcium-apoptosis link. Nat Rev Mol Cell Biol. 2003; 4: 552-65.

90. Wu TT, Peters AA, Tan PT, Roberts-Thomson SJ, Monteith GR. Consequences of activating the calcium-permeable ion channel TRPV1 in breast cancer cells with regulated TRPV1 expression. Cell Calcium. 2014; 56: 59-67.

91. Contassot E, Tenan M, Schnuriger V, Pelte MF, Dietrich PY. Arachidonyl ethanolamide induces apoptosis of uterine cervix cancer cells via aberrantly expressed vanilloid receptor-1. Gynecol Oncol. 2004; 93: 182-8.

92. Chien CS, Ma KH, Lee HS, Liu PS, Li YH, Huang YS, et al. Dual effect of capsaicin on cell death in human osteosarcoma G292 cells. Eur J Pharmacol. 2013; 718: 350-60.

93. Naziroglu M, Cig B, Blum W, Vizler C, Buhala A, Marton A, et al. Targeting breast cancer cells by MRS1477, a positive allosteric modulator of TRPV1 channels. PLoS One. 2017; 12: e0179950.

94. Fonseca BM, Correia-da-Silva G, Teixeira NA. Cannabinoid-induced cell death in endometrial cancer cells: involvement of TRPV1 receptors in apoptosis. J Physiol Biochem. 2018; 74: 261-72.

95. Adinolfi B, Romanini A, Vanni A, Martinotti E, Chicca A, Fogli S, et al. Anticancer activity of anandamide in human cutaneous melanoma cells. Eur J Pharmacol. 2013; 718: 154-9.

96. Soliman E, Van Dross R. Anandamide-induced endoplasmic reticulum stress and apoptosis are mediated by oxidative stress in non-melanoma skin cancer: Receptor-independent endocannabinoid signaling. Mol Carcinog. 2016; 55: 1807-21.

97. Ghosh AK, Basu S. Fas-associated factor 1 is a negative regulator in capsaicin induced cancer cell apoptosis. Cancer Lett. 2010; 287: 142-9.

98. Lau JK, Brown KC, Dom AM, Witte TR, Thornhill BA, Crabtree CM, et al. Capsaicin induces apoptosis in human small cell lung cancer via the TRPV6 receptor and the calpain pathway. Apoptosis. 2014; 19: 1190-201.

99. Chow J, Norng M, Zhang J, Chai J. TRPV6 mediates capsaicin-induced apoptosis in gastric cancer cells--Mechanisms behind a possible new "hot" cancer treatment. Biochim Biophys Acta. 2007; 1773: 565-76.

100. Eichele K, Ramer R, Hinz B. R(+)-methanandamide-induced apoptosis of human cervical carcinoma cells involves a cyclooxygenase-2-dependent pathway. Pharm Res. 2009; 26: 346-55.

101. Farfariello V, Liberati S, Morelli MB, Tomassoni D, Santoni M, Nabissi M, et al. Resiniferatoxin induces death of bladder cancer cells associated with mitochondrial dysfunction and reduces tumor growth in a xenograft mouse model. Chem Biol Interact. 2014; 224: 128-35.

102. Gonzales CB, Kirma NB, De La Chapa JJ, Chen R, Henry MA, Luo S, et al. Vanilloids induce oral cancer apoptosis independent of TRPV1. Oral Oncol. 2014; 50: 437-47.

103. Chaffer CL, Weinberg RA. A perspective on cancer cell metastasis. Science. 2011; 331: 1559-64.

104. Prevarskaya N, Ouadid-Ahidouch H, Skryma R, Shuba Y. Remodelling of Ca2+ transport in cancer: how it contributes to cancer hallmarks? Philos Trans R Soc Lond B Biol Sci. 2014; 369: 20130097.

105. Kadio B, Yaya S, Basak A, Dje K, Gomes J, Mesenge C. Calcium role in human carcinogenesis: a comprehensive analysis and critical review of literature. Cancer Metastasis Rev. 2016; 35: 391-411.

106. Villalobo A, Berchtold MW. The Role of Calmodulin in Tumor Cell Migration, Invasiveness, and Metastasis. Int J Mol Sci. 2020; 21.
107. Vriens J, Janssens A, Prenen J, Nilius B, Wondergem R. TRPV channels and modulation by hepatocyte growth factor/scatter factor in human hepatoblastoma (HepG2) cells. Cell Calcium. 2004; 36: 19-28.

108. Waning J, Vriens J, Owsianik G, Stuwe L, Mally S, Fabian A, et al. A novel function of capsaicin-sensitive TRPV1 channels: involvement in cell migration. Cell Calcium. 2007; 42: 17-25.

109. Nakanishi M, Morita Y, Hata K, Muragaki Y. Acidic microenvironments induce lymphangiogenesis and IL-8 production via TRPV1 activation in human lymphatic endothelial cells. Exp Cell Res. 2016; 345: 180-9.

110. Ramer R, Hinz B. Inhibition of cancer cell invasion by cannabinoids via increased expression of tissue inhibitor of matrix metalloproteinases-1. J Natl Cancer Inst. 2008; 100: 59-69.

111. Xu S, Zhang L, Cheng X, Yu H, Bao J, Lu R. Capsaicin inhibits the metastasis of human papillary thyroid carcinoma BCPAP cells through the modulation of the TRPV1 channel. Food Funct. 2018; 9: 344-54.

112. Lazzeri M, Vannucchi MG, Spinelli M, Bizzoco E, Beneforti P, Turini D, et al. Transient receptor potential vanilloid type 1 (TRPV1) expression changes from normal urothelium to transitional cell carcinoma of human bladder. Eur Urol. 2005; 48: 691-8

113. Kalogris C, Caprodossi S, Amantini C, Lambertucci F, Nabissi M, Morelli MB, et al. Expression of transient receptor potential vanilloid-1 (TRPV1) in urothelial cancers of human bladder: relation to clinicopathological and molecular parameters. Histopathology. 2010; 57: 744-52.

114. Ramer R, Bublitz K, Freimuth N, Merkord J, Rohde H, Haustein M, et al Cannabidiol inhibits lung cancer cell invasion and metastasis via intercellular adhesion molecule-1. FASEB J. 2012; 26: 1535-48.

115. Caprodossi S, Amantini C, Nabissi M, Morelli MB, Farfariello V, Santoni M, et al. Capsaicin promotes a more aggressive gene expression phenotype and invasiveness in null-TRPV1 urothelial cancer cells. Carcinogenesis. 2011; 32: 686-94.

116. Caballero FJ, Soler-Torronteras R, Lara-Chica M, Garcia V, Fiebich BL, Munoz E, et al. AM404 inhibits NFAT and NF-kappaB signaling pathways and impairs migration and invasiveness of neuroblastoma cells. Eur J Pharmacol. 2015; 746: 221-32.

117. Punzo F, Tortora C, Di Pinto D, Pota E, Argenziano M, Di Paola A, et al. Bortezomib and endocannabinoid/endovanilloid system: a synergism in osteosarcoma. Pharmacol Res. 2018; 137: 25-33.

118. Nishino $K$, Tanamachi $K$, Nakanishi $Y$, Ide $S$, Kojima S, Tanuma $S$, et al. Radiosensitizing Effect of TRPV1 Channel Inhibitors in Cancer Cells. Biol Pharm Bull. 2016; 39: 1224-30.

119. Masumoto K, Tsukimoto M, Kojima S. Role of TRPM2 and TRPV1 cation channels in cellular responses to radiation-induced DNA damage. Biochim Biophys Acta. 2013; 1830: 3382-90.

120. Nur G, Naziroglu M, Deveci HA. Synergic prooxidant, apoptotic and TRPV1 channel activator effects of alpha-lipoic acid and cisplatin in MCF-7 breast cancer cells. J Recept Signal Transduct Res. 2017; 37: 569-77.

121. Zheng L, Chen J, Ma Z, Liu W, Yang F, Yang Z, et al. Capsaicin enhances anti-proliferation efficacy of pirarubicin via activating TRPV1 and inhibiting PCNA nuclear translocation in 5637 cells. Mol Med Rep. 2016; 13: 881-7.

122. Kosar PA, Naziroglu M, Ovey IS, Cig B. Synergic Effects of Doxorubicin and Melatonin on Apoptosis and Mitochondrial Oxidative Stress in MCF-7 Breast Cancer Cells: Involvement of TRPV1 Channels. J Membr Biol. 2016; 249: 129-40.

123. Deveci HA, Naziroglu M, Nur G. 5-Fluorouracil-induced mitochondrial oxidative cytotoxicity and apoptosis are increased in MCF-7 human breast cancer cells by TRPV1 channel activation but not Hypericum perforatum treatment. Mol Cell Biochem. 2018; 439: 189-98.

124. Keating GM. Sorafenib: A Review in Hepatocellular Carcinoma. Target Oncol. 2017; 12: 243-53.

125. Sung B, Prasad S, Ravindran J, Yadav VR, Aggarwal BB. Capsazepine, a TRPV1 antagonist, sensitizes colorectal cancer cells to apoptosis by TRAIL through ROS-JNK-CHOP-mediated upregulation of death receptors. Free Radic Biol Med. 2012; 53: 1977-87.

126. Ribeiro Franco PI, Rodrigues AP, de Menezes LB, Pacheco Miguel M. Tumor microenvironment components: Allies of cancer progression. Pathol Res Pract. 2020; $216: 152729$.

127. Quail DF, Joyce JA. Microenvironmental regulation of tumor progression and metastasis. Nat Med. 2013; 19: 1423-37.

128. Balkwill FR, Capasso M, Hagemann T. The tumor microenvironment at a glance. J Cell Sci. 2012; 125: 5591-6.

129. Stewart TA, Yapa KT, Monteith GR. Altered calcium signaling in cancer cells. Biochim Biophys Acta. 2015; 1848: 2502-11.

130. Bong AHL, Monteith GR. Calcium signaling and the therapeutic targeting of cancer cells. Biochim Biophys Acta Mol Cell Res. 2018; 1865: 1786-94.

131. Roberts-Thomson SJ, Chalmers SB, Monteith GR. The Calcium-Signaling Toolkit in Cancer: Remodeling and Targeting. Cold Spring Harb Perspect Biol. 2019; 11.

132. Kalluri R, Zeisberg M. Fibroblasts in cancer. Nat Rev Cancer. 2006; 6: 392-401.

133. Kalluri R. The biology and function of fibroblasts in cancer. Nat Rev Cancer. 2016; 16: 582-98

134. Ishimoto T, Miyake K, Nandi T, Yashiro M, Onishi N, Huang KK, et al. Activation of Transforming Growth Factor Beta 1 Signaling in Gastric Cancer-associated Fibroblasts Increases Their Motility, via Expression of Rhomboid 5 Homolog 2, and Ability to Induce Invasiveness of Gastric Cancer Cells. Gastroenterology. 2017; 153: 191-204 e16. 
135. Aoyagi $\mathrm{Y}$, Oda $\mathrm{T}$, Kinoshita $\mathrm{T}$, Nakahashi $\mathrm{C}$, Hasebe $\mathrm{T}$, Ohkohchi $\mathrm{N}$, et al. Overexpression of TGF-beta by infiltrated granulocytes correlates with the expression of collagen mRNA in pancreatic cancer. Br J Cancer. 2004; 91: 1316-26.

136. Yoshida GJ. Regulation of heterogeneous cancer-associated fibroblasts: the molecular pathology of activated signaling pathways. J Exp Clin Cancer Res. 2020; 39: 112.

137. Bodo E, Biro T, Telek A, Czifra G, Griger Z, Toth BI, et al. A hot new twist to hair biology: involvement of vanilloid receptor-1 (VR1/TRPV1) signaling in human hair growth control. Am J Pathol. 2005; 166: 985-98.

138. Okada Y, Reinach PS, Shirai K, Kitano A, Kao WW, Flanders KC, et al. TRPV1 involvement in inflammatory tissue fibrosis in mice. Am J Pathol. 2011; 178: 2654-64.

139. Li HJ, Kanazawa N, Kimura A, Kaminaka C, Yonei N, Yamamoto Y, et al. Severe ulceration with impaired induction of growth factors and cytokines in keratinocytes after trichloroacetic acid application on TRPV1-deficient mice. Eur J Dermatol. 2012; 22: 614-21.

140. Nidegawa-Saitoh Y, Sumioka T, Okada Y, Reinach PS, Flanders KC, Liu CY, et al. Impaired healing of cornea incision injury in a TRPV1-deficient mouse. Cell Tissue Res. 2018; 374: 329-38.

141. Mouw JK, Ou G, Weaver VM. Extracellular matrix assembly: a multiscale deconstruction. Nat Rev Mol Cell Biol. 2014; 15: 771-85.

142. Caires R, Luis E, Taberner FJ, Fernandez-Ballester G, Ferrer-Montiel A, Balazs EA, et al. Hyaluronan modulates TRPV1 channel opening, reducing peripheral nociceptor activity and pain. Nat Commun. 2015; 6: 8095.

143. Gonzalez-Avila G, Sommer B, Garcia-Hernandez AA, Ramos C. Matrix Metalloproteinases' Role in Tumor Microenvironment. Adv Exp Med Biol. 2020; 1245: 97-131.

144. Wu T, Dai Y. Tumor microenvironment and therapeutic response. Cancer Lett. 2017; 387: 61-8.

145. Li WH, Lee YM, Kim JY, Kang S, Kim S, Kim KH, et al. Transient receptor potential vanilloid-1 mediates heat-shock-induced matrix metalloproteinase-1 expression in human epidermal keratinocytes. J Invest Dermatol. 2007; 127: 2328-35.

146. Lee YM, Li WH, Kim YK, Kim KH, Chung JH. Heat-induced MMP-1 expression is mediated by TRPV1 through PKCalpha signaling in HaCaT cells. Exp Dermatol. 2008; 17: 864-70.

147. Huang KF, Ma KH, Chang YJ, Lo LC, Jhap TY, Su YH, et al. Baicalein inhibits matrix metalloproteinase 1 expression via activation of TRPV1-Ca-ERK pathway in ultraviolet B-irradiated human dermal fibroblasts. Exp Dermatol. 2019; 28: 568-75.

148. Ramer R, Merkord J, Rohde H, Hinz B. Cannabidiol inhibits cancer cell invasion via upregulation of tissue inhibitor of matrix metalloproteinases-1. Biochem Pharmacol. 2010; 79: 955-66.

149. Kohn EC, Alessandro R, Spoonster J, Wersto RP, Liotta LA. Angiogenesis: role of calcium-mediated signal transduction. Proc Natl Acad Sci U S A. 1995; 92: 1307-11.

150. Faehling M, Kroll J, Fohr KJ, Fellbrich G, Mayr U, Trischler G, et al. Essential role of calcium in vascular endothelial growth factor A-induced signaling: mechanism of the antiangiogenic effect of carboxyamidotriazole. FASEB J. 2002; 16: 1805-7.

151. Moccia F, Negri S, Shekha M, Faris P, Guerra G. Endothelial Ca(2+) Signaling, Angiogenesis and Vasculogenesis: just What It Takes to Make a Blood Vessel. Int J Mol Sci. 2019; 20.

152. Munaron L. Intracellular calcium, endothelial cells and angiogenesis. Recent Pat Anticancer Drug Discov. 2006; 1: 105-19.

153. Earley S, Brayden JE. Transient receptor potential channels in the vasculature. Physiol Rev. 2015; 95: 645-90.

154. Nishida N, Yano H, Nishida T, Kamura T, Kojiro M. Angiogenesis in cancer. Vasc Health Risk Manag. 2006; 2: 213-9.

155. Apte RS, Chen DS, Ferrara N. VEGF in Signaling and Disease: Beyond Discovery and Development. Cell. 2019; 176: 1248-64.

156. Winder T, Lenz HJ. Vascular endothelial growth factor and epidermal growth factor signaling pathways as therapeutic targets for colorectal cancer. Gastroenterology. 2010; 138: 2163-76.

157. Ferrara N, Gerber HP, LeCouter J. The biology of VEGF and its receptors. Nat Med. 2003; 9: 669-76.

158. Walcher L, Budde C, Bohm A, Reinach PS, Dhandapani P, Ljubojevic N, et al. TRPM8 Activation via 3-Iodothyronamine Blunts VEGF-Induced Transactivation of TRPV1 in Human Uveal Melanoma Cells. Front Pharmacol. 2018; 9: 1234.

159. Su KH, Lin SJ, Wei J, Lee KI, Zhao JF, Shyue SK, et al. The essential role of transient receptor potential vanilloid 1 in simvastatin-induced activation of endothelial nitric oxide synthase and angiogenesis. Acta Physiol (Oxf). 2014; 212: 191-204.

160. Vinuesa AG, Sancho R, Garcia-Limones C, Behrens A, ten Dijke P, Calzado $\mathrm{MA}$, et al. Vanilloid receptor-1 regulates neurogenic inflammation in colon and protects mice from colon cancer. Cancer Res. 2012; 72: 1705-16.

161. Gao P, Niu N, Wei T, Tozawa $H$, Chen X, Zhang C, et al. The roles of signal transducer and activator of transcription factor 3 in tumor angiogenesis. Oncotarget. 2017; 8: 69139-61.

162. Atsumi T, Singh R, Sabharwal L, Bando H, Meng J, Arima $\mathrm{Y}$, et al. Inflammation amplifier, a new paradigm in cancer biology. Cancer Res. 2014; 74: 8-14.
163. Wang S, Liu Z, Wang L, Zhang X. NF-kappaB signaling pathway, inflammation and colorectal cancer. Cell Mol Immunol. 2009; 6: 327-34.

164. Coussens LM, Werb Z. Inflammation and cancer. Nature. 2002; 420: 860-7.

165. Ritter B, Greten FR. Modulating inflammation for cancer therapy. J Exp Med. 2019; 216: 1234-43.

166. Greten FR, Grivennikov SI. Inflammation and Cancer: Triggers, Mechanisms, and Consequences. Immunity. 2019; 51: 27-41.

167. Vig M, Kinet JP. Calcium signaling in immune cells. Nat Immunol. 2009; 10: 21-7.

168. Oh-hora M, Rao A. Calcium signaling in lymphocytes. Curr Opin Immunol. 2008; 20: 250-8

169. Bertin S, Aoki-Nonaka Y, de Jong PR, Nohara LL, Xu H, Stanwood SR, et al. The ion channel TRPV1 regulates the activation and proinflammatory properties of CD4(+) T cells. Nat Immunol. 2014; 15: 1055-63.

170. Basu S, Srivastava P. Immunological role of neuronal receptor vanilloid receptor 1 expressed on dendritic cells. Proc Natl Acad Sci U S A. 2005; 102: 5120-5.

171. Erin N. Role of sensory neurons, neuroimmune pathways, and transient receptor potential vanilloid 1 (TRPV1) channels in a murine model of breast cancer metastasis. Cancer Immunol Immunother. 2020; 69: 307-14. 